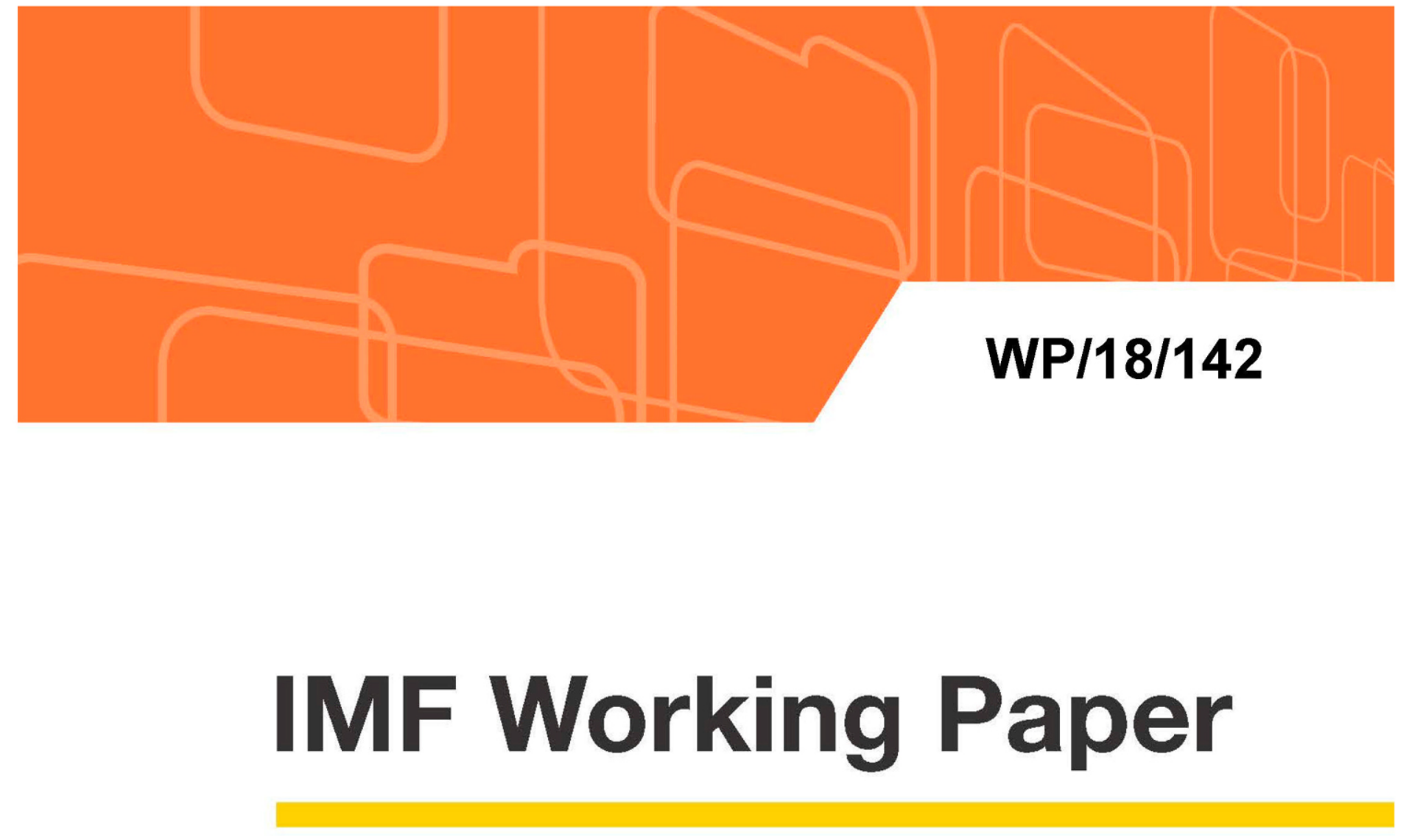

\title{
The Macroeconomic Effects of Fiscal Consolidation in Emerging Economies: Evidence from Latin America
}

by Yan Carrière-Swallow, Antonio C. David, and Daniel Leigh

IMF Working Papers describe research in progress by the author(s) and are published to elicit comments and to encourage debate. The views expressed in IMF Working Papers are those of the author(s) and do not necessarily represent the views of the IMF, its Executive Board, or IMF management. 


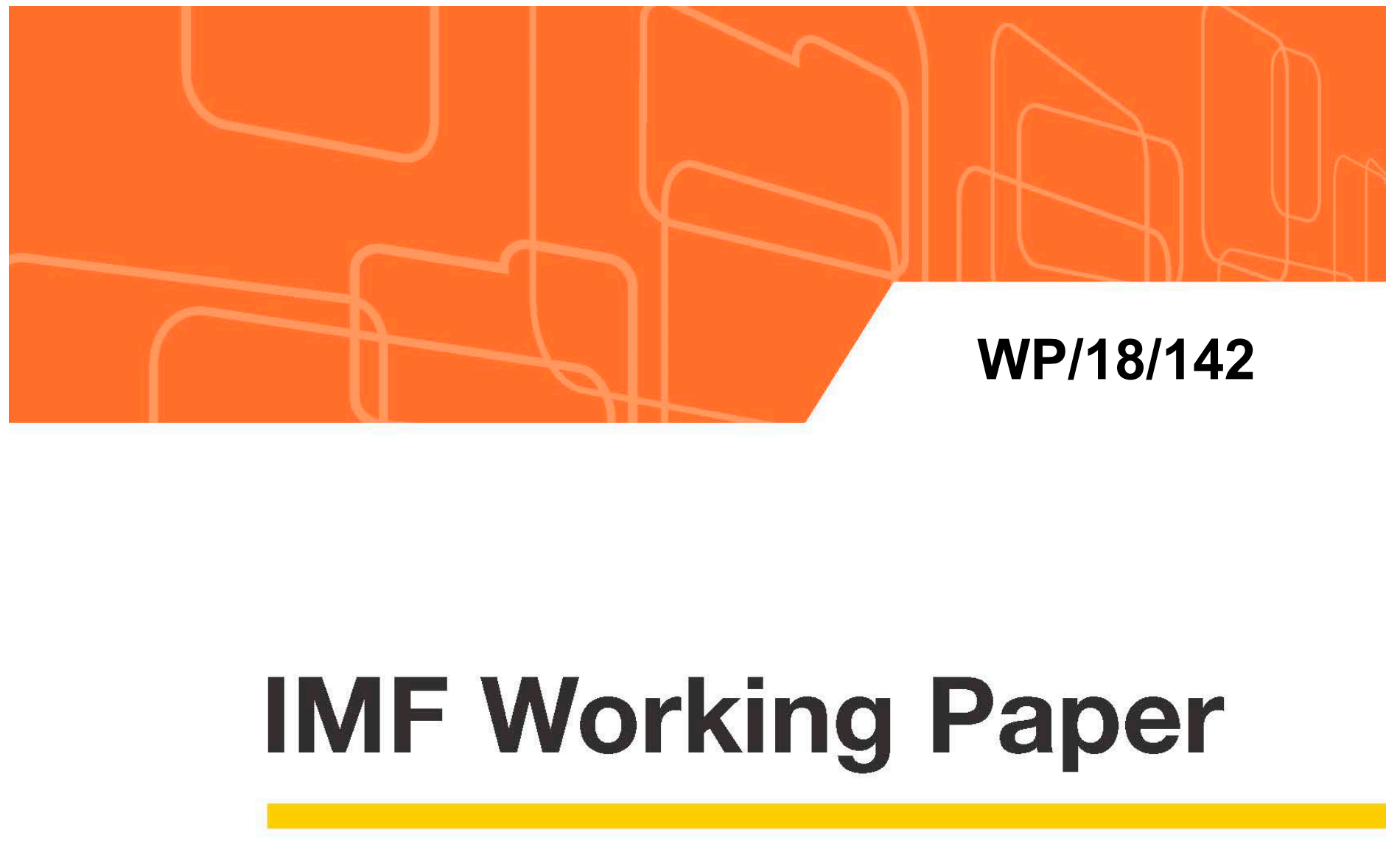

\title{
The Macroeconomic Effects of Fiscal Consolidation in Emerging Economies: Evidence from Latin America
}

\author{
by Yan Carrière-Swallow, Antonio C. David, and Daniel Leigh
}

IMF Working Papers describe research in progress by the author(s) and are published to elicit comments and to encourage debate. The views expressed in IMF Working Papers are those of the author(s) and do not necessarily represent the views of the IMF, its Executive Board, or IMF management. 


\title{
IMF Working Paper
}

Western Hemisphere Department

\section{The Macroeconomic Effects of Fiscal Consolidation in Emerging Economies: Evidence from Latin America ${ }^{1}$}

\author{
Prepared by Yan Carrière-Swallow, Antonio C. David, and Daniel Leigh
}

Authorized for distribution by Hamid Faruqee

June 2018

\section{IMF Working Papers describe research in progress by the author(s) and are published to elicit comments and to encourage debate. The views expressed in IMF Working Papers are those of the author(s) and do not necessarily represent the views of the IMF, its Executive Board, or IMF management.}

\begin{abstract}
We estimate the short-term effects of fiscal consolidation on economic activity in 14 countries in Latin America and the Caribbean. We examine contemporaneous policy documents to identify changes in fiscal policy motivated by a desire to reduce the budget deficit and not by responding to prospective economic conditions. Based on this narrative dataset, our estimates suggest that fiscal consolidation has contractionary effects on GDP, consistent with a multiplier of 0.9. We find these effects to be close to those in OECD countries based on a similarly constructed dataset (Devries and others, 2011). We also find similar estimation results for the two groups of economies for the effect of fiscal consolidation on the external current account balance, providing support for the twin deficits hypothesis.
\end{abstract}

JEL Classification Numbers: E62, H20, H5, H6

Keywords: Fiscal policy, fiscal consolidation, taxation, emerging market economies. Author's E-Mail Address: ycswallow@imf.org; adavid@,imf.org; dleigh@,imf.org

\footnotetext{
${ }^{1}$ We are grateful to Anja Baum, Dilyana Dimova, Raphael Espinoza, Hamid Faruqee, Jorge Restrepo, Galen Sher, Saji Thomas and numerous seminar participants at the IMF, at the Central Bank of Chile and at the Central Bank of Mexico for helpful comments. Genevieve Lindow provided superb research assistance.
} 


\section{INTRODUCTION}

Public debt has risen in many emerging market and developing economies (EMDEs), precipitating the need for fiscal consolidation. There is, however, no consensus in the literature regarding the size and even the sign of the macroeconomic effects of fiscal consolidation in EMDEs. There is also little agreement on how the effects compare with those in advanced economies (AEs).

Theory provides an ambiguous guide to the relative size of fiscal multipliers in EMDEs and AEs. Some factors imply larger multipliers in EMDEs, such as tighter liquidity constraints facing households and firms that imply a sharper reduction in private consumption and investment during periods of fiscal consolidation. But other factors imply smaller multipliers in EMDEs. For example, they typically feature higher perceived sovereign default risk, implying more scope for confidence effects that could partly offset the direct effects of fiscal consolidation (Blanchard, 1990, for example).

Existing empirical studies generally suggest that fiscal multipliers are smaller in EMDEs than in AEs. Our review of 133 recent estimates of fiscal multipliers finds that they are on average 50 percent larger for AEs than for EMDEs (Figure 1). ${ }^{2}$ However, methodological differences across the studies, as well as differences in data quality, may play a strong role in explaining this difference. Several recent studies for AEs use narrative methods, which draw on policy documents to identify the timing and intention of fiscal policy changes, with the goal of more precisely estimating causal effects (Romer and Romer 2010, for example). Such narrativebased studies often yield larger multiplier estimates than do the more conventional approaches - such as those based on cyclically adjusted fiscal data or the estimation of structural vector auto regressions (SVARs) — on which most studies for EMDEs rely. ${ }^{3}$ There is little available evidence based on such narrative approaches for EMDEs.

This paper attempts to fill this gap in the literature and provide fresh evidence on the macroeconomic effects of fiscal consolidation in EMDEs by constructing a new narrative dataset of fiscal consolidation episodes for 14 countries in Latin America and the Caribbean (LAC) for 1989-2016. Following the approach of narrative studies conducted for AEs, we examine the behavior of economic activity in LAC economies following discretionary changes in fiscal policy that, historical sources suggest, are not correlated with the short-term economic outlook. As we explain in Section II, we consult contemporaneous policy

\footnotetext{
${ }^{2}$ See Annex Table A1 for further details on the studies considered.

${ }^{3}$ Studies for AEs based on narrative methods, a number of which compare estimation results based on narrative approaches with those based on conventional approaches include, among others, Romer and Romer (2010), Ramey (2012), Guajardo, Leigh, and Pescatori (2014), and Jordà and Taylor (2015).
} 


\section{Figure 1. Distribution of Empirical Multiplier Estimates by Country Group}

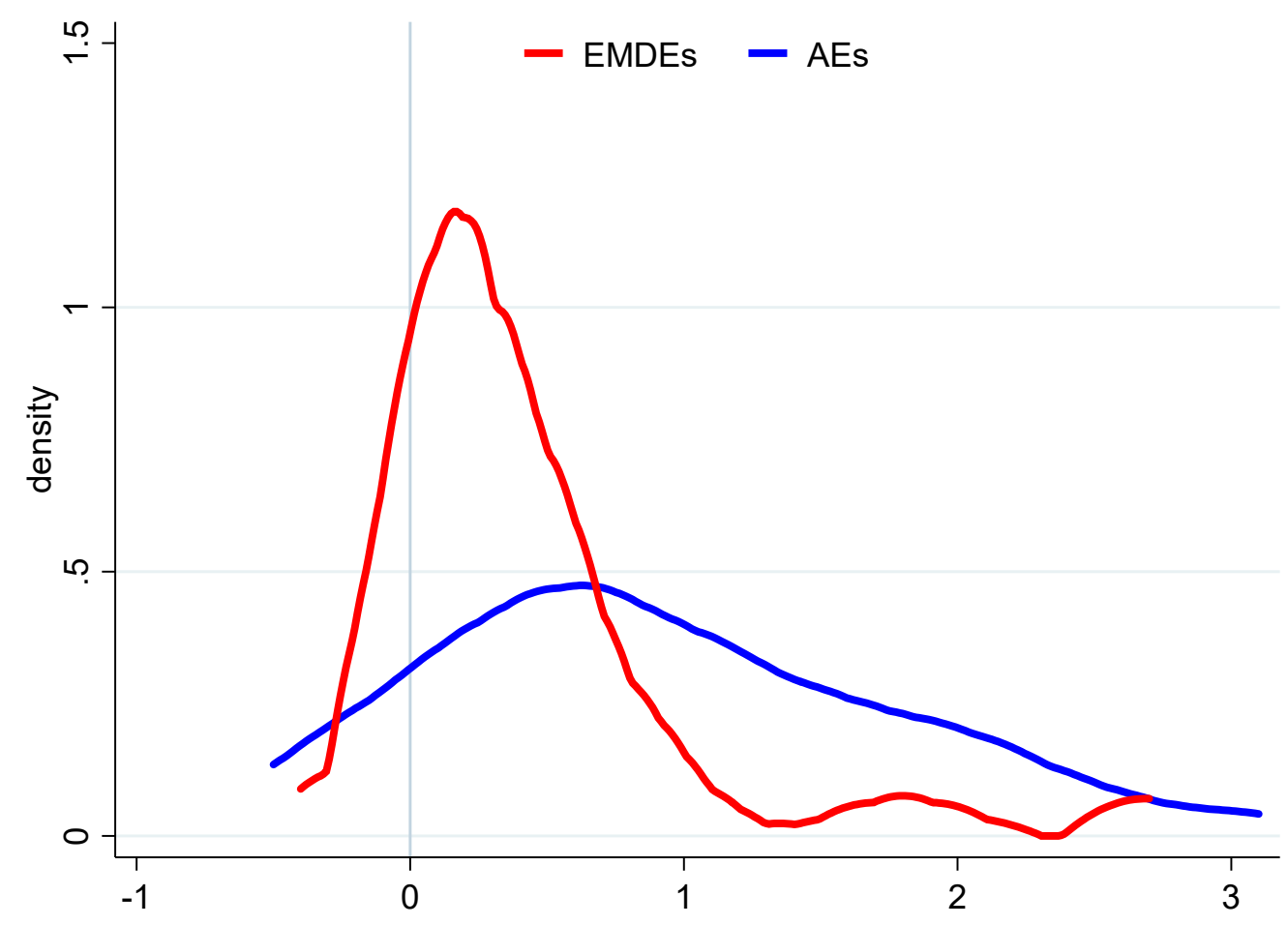

documents to identify fiscal actions motivated by a desire to reduce the budget deficit and ensure long-term public financial sustainability, rather than to prevent abnormal growth or respond to cyclical pressures. ${ }^{4}$ Our approach is closest to that of Devries and others (2011), who construct such a dataset for 17 OECD economies.

Based on our new dataset, we estimate the effects of fiscal consolidation for LAC economies. As Section III explains, our baseline specification uses the local projection method (LP) proposed by Jordà (2005). The estimation results, reported in Section IV, suggest that fiscal consolidation in our sample of LAC economies are typically associated with contractions in output, consistent with an average fiscal multiplier of about 0.9. This estimate is about three times larger than the average of multiplier estimates across existing empirical studies available for LAC economies (as reported in the Annex). Interestingly, our estimation results for LAC economies are very similar to those we obtain for AEs using a comparable narrative dataset (Devries and others, 2011). The results hold up to a battery of robustness checks.

\footnotetext{
${ }^{4}$ See studies such as Romer and Romer (2010) and Guajardo, Leigh, and Pescatori (2014) for a discussion of how estimates based on cyclically-adjusted fiscal variables or SVARs can be biased toward understating the size of fiscal multipliers.
} 
To explore the channels at work and shed light on the factors that shape fiscal multipliers, we extend the analysis in three directions. First, we investigate the effects of fiscal consolidation on the unemployment rate, private consumption and private investment, the external current account balance, and the real exchange rate. Second, we assess whether the effects of fiscal consolidation depend on the initial level of sovereign default risk and the state of the business cycle. Finally, we investigate how the output effects of fiscal consolidation depend on the composition of the consolidation package across spending and tax measures. Section IV concludes the paper.

\section{Identifying Fiscal Consolidation: A NeW Narrative Dataset}

We construct a new dataset of fiscal consolidation measures taken by the governments of 14 LAC economies to reduce budget deficits during 1989-2016. The approach builds on earlier work by Devries and others (2011) that identified such fiscal consolidation measures for 17 OECD economies. Additional documentation on each fiscal policy change can be found in our companion paper, David and Leigh (2018), in which we provide detailed citations for each data point to show how we determine the motivation and estimated budgetary effects from the historical record.

Following the approach of Romer and Romer (2010) and Devries and others (2011), we examine contemporaneous policy documents to assess the motivation, expected size, and timing of discretionary policy actions, including changes in both taxes or spending. We focus on policy actions that are not driven by a desire to respond to current or prospective economic conditions, but that are instead motivated by considerations such as reducing an inherited budget deficit and ensuring long-term public financial sustainability. ${ }^{5}$ There are some cases of fiscal actions that imply expansions in the budget deficit that are motivated by such long-term objectives. Whenever such fiscal actions occur, we record them in the dataset with a negative sign. The measures of the magnitude of fiscal policy changes included in the database rely on estimates of the revenue or expenditure impact of the given policy action at the time of implementation (expressed in annual terms) and at the prevailing level of GDP.

A possible concern regarding our narrative approach, highlighted by Jordà and Taylor (2015), is that such fiscal consolidation episodes reflect past economic developments and could thus have a forecastable component. We address this concern in Section III by applying the Jordà and Taylor (2015) augmented inverse propensity score weighting procedure.

\footnotetext{
${ }^{5}$ In that context, if the fiscal consolidation is motivated primarily by restraining domestic demand or in response to an economic contraction, we do not include it in our database. Other long-run considerations deemed to be motivations for exogenous fiscal actions could include measures aimed at reducing inequality, improving incentives, or increasing efficiency, or could stem from a philosophical belief in the benefits of small government (Romer and Romer, 2010).
} 
We only include in the dataset fiscal measures that were implemented, according to historical policy documents. If measures were announced but did not come into effect, we do not include them in the database. For example, the government of Costa Rica announced a consolidation package in 1990 that in addition to revenue measures amounting to 1.5 percent of GDP, also envisaged 2 percent of GDP in expenditure cuts. As the latter were not implemented, we only include the revenue measures in the dataset. Occasionally, announced measures are only partly implemented or are implemented with delays and the coding of the budgetary impacts in the dataset takes these features into account.

The narrative approach we use is motivated by reducing estimation biases associated with conventional approaches for identifying the causal effects of fiscal policy. As a number of studies explain, measuring changes in fiscal policy based on changes in the cyclicallyadjusted primary balance (CAPB) - a conventional approach — can be problematic. The CAPB includes shifts in fiscal variables unrelated to policy decisions - including those driven by swings in asset or commodity prices, which also affect economic activity. A commodity price boom may, for example, stimulate private investment while also boosting government revenue. Another shortcoming is that changes in the CAPB may reflect policy responses to current macroeconomic conditions, such as a loosening of fiscal policy motivated by the onset of a recession.

A related literature identifies fiscal policy shocks using structural VARs. The pioneering work of Blanchard and Perotti (2002) applies this approach to quarterly data for the United States. As Romer and Romer (2010) point out, even this more refined approach still assumes that, after controlling for lags of output growth, changes in government revenue and spending are uncorrelated with other short-term developments affecting output. It therefore ignores the issue of nonpolicy changes in cyclically-adjusted fiscal data. This concern is particularly relevant when using annual data, as is typically the case for studies focusing on EMDEs. ${ }^{6}$

The dataset contains 76 observations with non-zero fiscal actions over the period of 19892016. Each fiscal action is expressed in terms of its budgetary impact as a share of GDP, as listed in the Annex, and is described in detail in David and Leigh (2018). In a number of cases, these actions enter the database with a negative sign, as in the case of temporary tax increases that are subsequently reversed. Figure 2 reports the density function for the size of the identified fiscal actions. The average budgetary impact (conditional on an action occurring) is 0.9 percent of GDP., with a standard deviation of about 1 percent of GDP.

\footnotetext{
${ }^{6}$ Riera-Crichton, Végh, and Vuletin (2016) show that when using identification strategies based on structural VARs, various tax series respond to output fluctuations, suggesting that presumed exogenous changes in fiscal policy (at a one quarter horizon) may in fact be anticipated by economic agents. They argue that the sign of the bias introduced in multiplier estimates using this approach depend on the cyclicality of fiscal policy, which varies across emerging and advanced economies. The use of real-time forecast errors in fiscal variables is another alternative approach (Auerbach and Gorodnichenko, 2013; Furceri and Li, 2017) although this too can lead to the introduction of measurement error due to changes in non-policy factors.
} 


\section{Figure 2. Distribution of Budgetary Impact of Narrative Fiscal Shocks (Percent of GDP)}

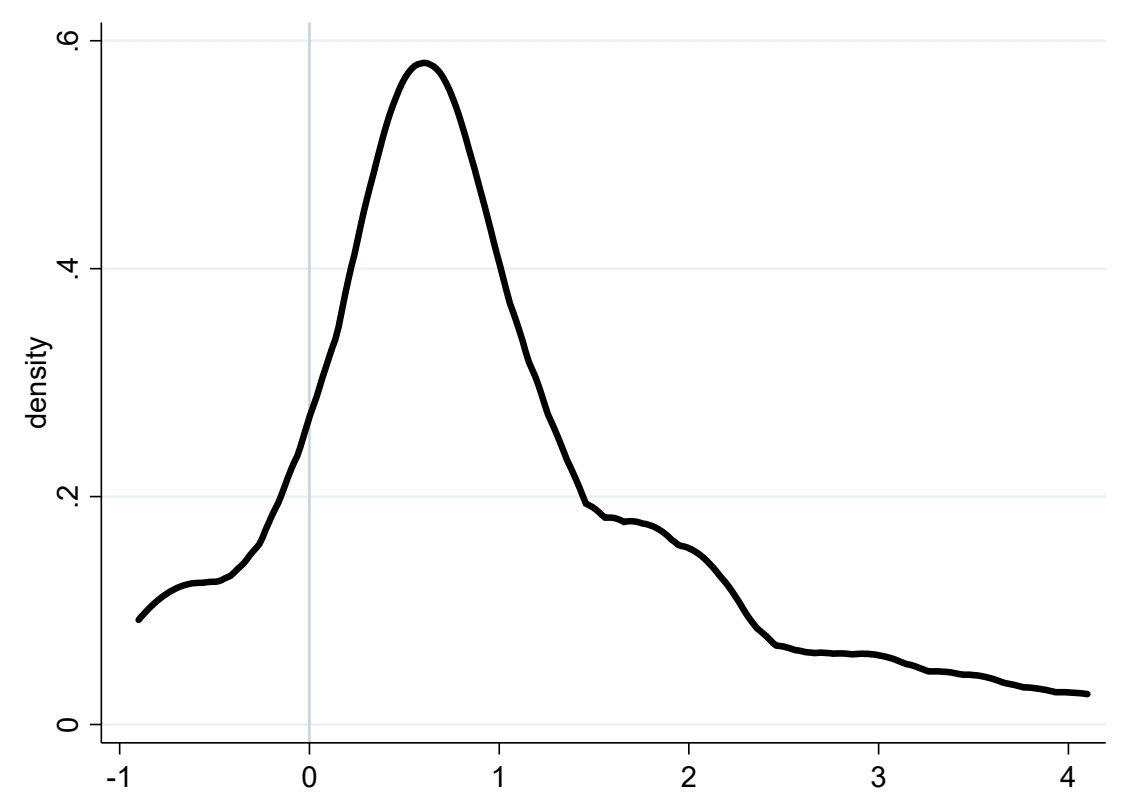

We further classify the consolidation episodes as "tax-based" or "expenditure-based" depending on whether tax hikes or expenditure cuts account for most of the budgetary impact of the consolidation (Guajardo, Leigh and Pescatori, 2014). ${ }^{7}$ There are 55 observations for tax-based consolidations and 18 for expenditure-based episodes. Expenditure-based consolidations are somewhat larger in size at about 1.2 percent of GDP, which compares to 0.8 percent of GDP for tax-based consolidations.

An important feature of this narrative approach is the coverage of fiscal actions across both revenue and spending instruments, which allows us to control for offsetting measures that may be deployed as part of a package. In an important recent contribution, Gunter and others (2017) construct a comprehensive dataset of changes in VAT rates across numerous economies. VAT rate changes might, however, be accompanied by changes in other taxes or government spending that are not included in the study.

To shed light on how our narrative approach for measuring fiscal changes compares with more conventional measures, we compare our narrative episodes with the change in the cyclically-adjusted primary balance (CAPB) reported in the October 2017 IMF World Economic Outlook (WEO) database. As a series for the CAPB is not available in the WEO database for some of the14 LAC economies in our sample, we construct a measure of the CAPB based on conventional procedures, as we explain in the Annex.

\footnotetext{
${ }^{7}$ In three cases (Costa Rica 2016; Jamaica 2003 and 2004), the packages are balanced between tax hikes and spending cuts, so we do not classify them in either category.
} 
Figure 3. Two Measures of Fiscal Consolidation: Changes in CAPB versus Narrative Fiscal shocks (Percent of GDP)

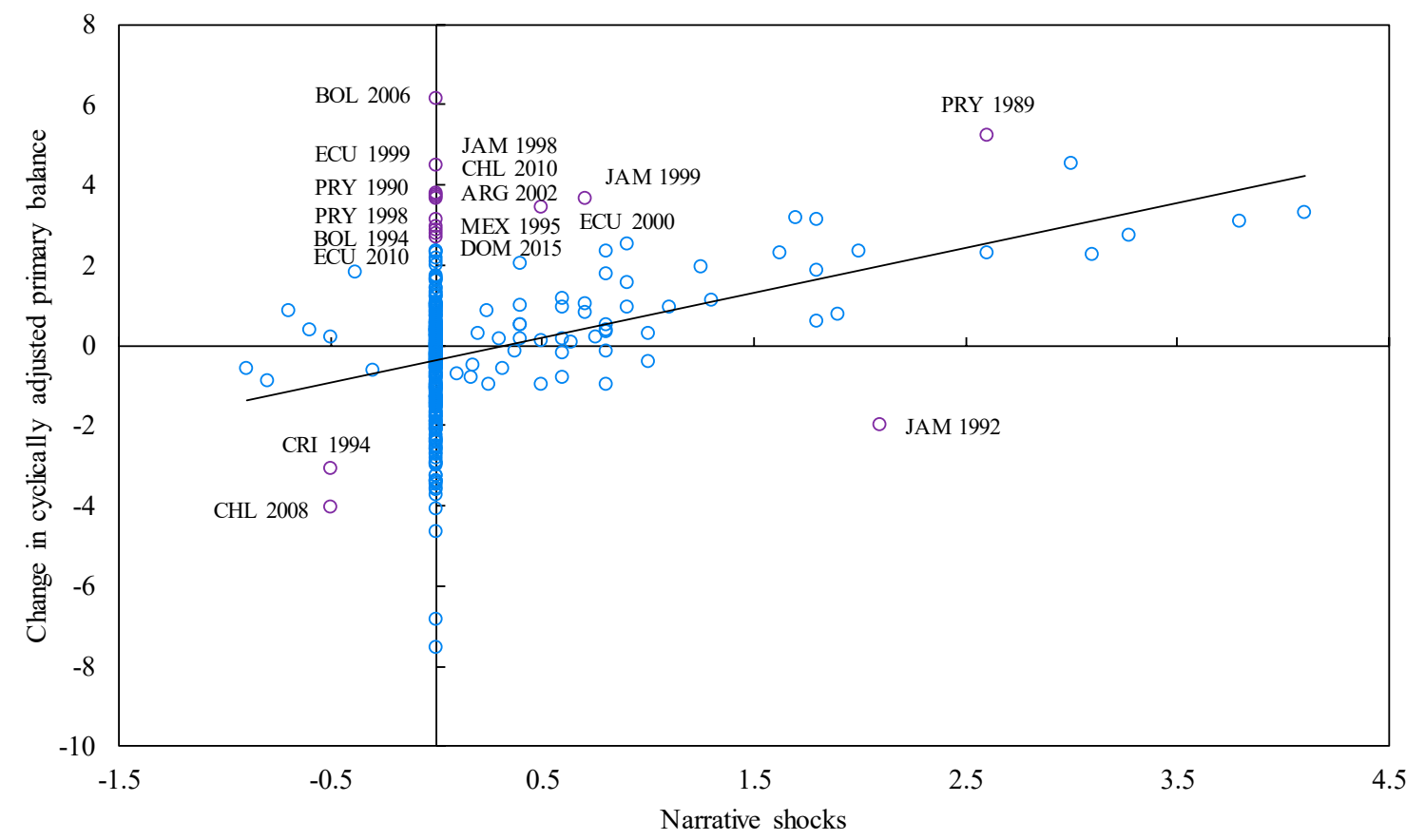

Notes: Labels indicate cases where either the CAPB or the narrative approach identify fiscal consolidation and the discrepancy between the two measures exceeds 2.5 percent of GDP. Labels indicate three-letter ISO country codes. The diagonal line indicates points along which the series are equal ( $45^{\circ}$ line).

Figure 3 plots the episodes identified through the narrative analysis against the contemporaneous change in the CAPB. The correlation between the two measures is strong. However, there are numerous cases in which the CAPB approach and our narrative approach come to different conclusions regarding the presence and size of fiscal consolidation. Our inspection of the 16 largest discrepancies - detailed in the Annex - suggests that our narrative approach more accurately identifies the size of deficit-driven fiscal consolidation. The discrepancies are generally driven by specific economic or budgetary developments that cause the conventional CAPB-based measure to inaccurately identify the size of deficitdriven fiscal consolidation. These developments include, in a number of cases, responses to current or prospective economic conditions, including the onset of economic crisis.

\section{Orthogonality to News Regarding the State of the Economy}

The narrative approach aims to identify fiscal policy changes that are exogenous to current and prospective news about the state of the economy. To ensure that this is the case, we follow Guajardo, Leigh and Pescatori (2014) and test whether the narrative fiscal shocks are correlated with unexpected movements in output. We construct a measure of economic news 
Table 1. Regressions of fiscal actions on economic news

\begin{tabular}{lcccc}
\multicolumn{4}{c}{ Equation: $F C_{i, t}=\alpha_{i}+\gamma_{t}+\beta N e w s_{i, t}+\varepsilon_{i, t}$} \\
\hline Narrative shocks in: & $\hat{\beta}$ & Std. Err. & $\mathrm{R}^{2}$ & $\mathrm{~N}$ \\
\hline Latin America & -0.04 & $(0.03)$ & 0.16 & 364 \\
Advanced economies & -0.08 & $(0.05)$ & 0.34 & 403 \\
\hline
\end{tabular}

Notes: Regressions are estimated for 1989 - 2016. The table reports point estimates and heteroskedasticity-robust standard errors. See the text for description of the News variable.

* Significant at $10 \%$;* significant at $5 \%$; ** significant at $1 \%$.

based on real-time revisions to forecasts of real GDP published in the IMF's World Economic Outlook database. These are defined as the revision to the forecast for current-year GDP made in the fall of year $t$ relative to the forecast made in the fall of the previous year ( $t$ 1). We then regress our series of narrative fiscal shocks on this measure of economic news.

The results of this test are reported in Table 1. We find that the narrative fiscal consolidations are not significantly related to contemporaneous unexpected movements in output, both in an economic and a statistical sense. This conclusion is valid for emerging as well as for advanced economy samples. It is worth emphasizing that the finding that the narrative fiscal shocks are orthogonal to current economic developments does not imply that they are unrelated to past developments. Indeed, since the fiscal consolidations we identify are motivated by reducing inherited budget deficits, they are likely to be correlated with past developments and should thus be predictable to some extent. In the robustness section, we estimate fiscal multipliers using an average treatment effect that takes the predictability of the shocks into account.

\section{EMPIRICAL STRATEGY}

We estimate the macroeconomic effects of fiscal consolidations using the local projection method (LP) proposed by Jordà (2005). One of the advantages of this procedure is that it does not constrain the shape of the impulse response functions, and is therefore less sensitive to misspecification than estimates obtained from VAR models. Another advantage is its flexibility in estimating state-dependent impulse responses. Importantly for the extensions we will undertake in Section IV, there is no need to make assumptions about transition probabilities across states and about the feedback between shocks and states, as LP estimates already incorporate average transition characteristics from the data (Ramey and Zubairy, 2018).

The benchmark specification for different horizons $(h=0,1,2)$ in years is as follows:

$$
y_{i, t+h}-y_{i, t-1}=\alpha_{i}^{h}+\gamma_{t}^{h}+\beta^{h} \sum_{s=t}^{t+h} F C_{i, s}+\delta X_{i, t}+\varepsilon_{i, t+h},
$$


where $y$ is the macroeconomic variable of interest (the log of real GDP, the current account balance as a share of GDP, or the log of the real effective exchange rate, among other variables); $F C$ denotes our measure of fiscal consolidation in percent of GDP; and $X_{t}$ is a set of control variables that includes two lags of real GDP growth and two lags of the fiscal shocks. We include time $\left(\gamma_{t}^{h}\right)$ and country $\left(\alpha_{i}^{h}\right)$ fixed effects to capture common shocks and time-invariant features of fiscal policy and growth, respectively. The vector of controls $X_{t}$ also includes the contemporaneous growth rate of the commodity export value and its lags, which is an important driver of business cycles and fiscal policy in EMDEs (Céspedes and Velasco, 2014; Fernández, González and Rodríguez, 2018).

The coefficient $\beta^{h}$ corresponds to our multiplier estimate. Following Ramey and Zubairy (2018), we define fiscal multipliers as the response of the level of real GDP —or the relevant macroeconomic variable of interest - relative to the cumulative fiscal shock over a given horizon. ${ }^{8}$ Alternative definitions of fiscal multipliers have been frequently considered in the literature, such as the ratio of the peak of the output level response to an initial government spending/tax shock (Blanchard and Perotti, 2002) or the ratio of the average output response to an initial fiscal policy shock (Auerbach and Gorodnichenko, 2012). However, it is important to calculate multipliers by comparing the integral of output responses to the integral of fiscal shocks (rather than impact effects) because the effects of fiscal policy can either build or be reverted over time.

The regressions are estimated by ordinary least squares with the narrative shocks included directly in the panel models. The annex presents the definitions and sources for the variables used in the analysis.

\section{Results}

\section{A. Fiscal Multipliers in Emerging Economies}

Figure 4 reports impulse responses obtained from estimation of Equation 1. The shaded regions indicate 90 percent confidence intervals based on Driscoll-Kraay standard errors that are robust to autocorrelation and cross-sectional dependence. The figure displays the response of the level of real GDP following a fiscal shock of 1 percent of GDP, and thus corresponds to the output multiplier estimate at each horizon. We find that fiscal consolidations in LAC economies lead to an output contraction of 0.5 percent on impact and of 0.9 percent after two years, with a 90 percent confidence interval of $0.6-1.2$ percent.

We then compare these responses to a group of advanced economies, using the same methodology. To do so, we re-estimate Equation 1 using the narrative fiscal shocks constructed by Devries and others (2011) for 17 OECD economies covering the period 1978-

\footnotetext{
${ }^{8}$ These have been referred to as "integral multipliers."
} 
Figure 4. Real GDP: Estimated Effect of a 1 Percent of GDP Fiscal Consolidation
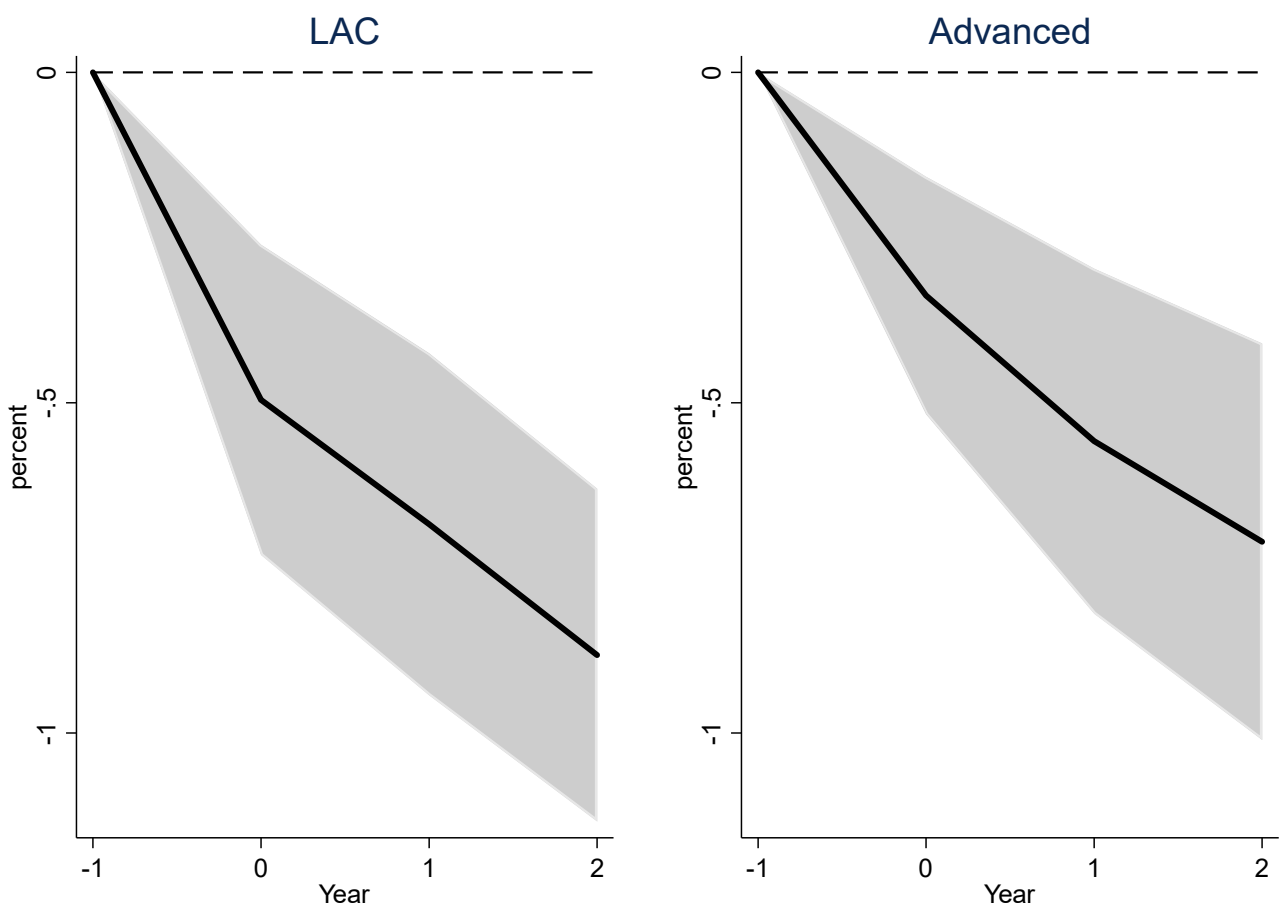

Note: Shading indicates 90 percent confidence interval.

2009, which we extend through 2014 based on the narrative dataset of Alesina and others (2018). In this comparator group, fiscal consolidations are estimated to lead to a fall in output of 0.3 percent on impact, rising to 0.7 percent after two years.

In contrast to the literature, we conclude that the average output responses for these two groups of emerging market and advanced economies are similar, with point estimates within one standard error of each other at horizons of 1 and 2 years. This result may reflect the fact that we are using a common narrative identification strategy and common estimation specification across groups, whereas the literature has tended to use different strategies across samples.

\section{B. Robustness Checks}

Table 2 reports the sensitivity of the baseline results to a series of robustness checks, focusing on the multiplier estimates on impact $(h=0)$ and after two years $(h=2)$. 
Table 2. Estimation Results: Effect of a 1 Percent of GDP Fiscal Consolidation in year $t+h$ (Percent).

\begin{tabular}{|c|c|c|c|c|}
\hline \multirow{2}{*}{ Specification } & \multicolumn{4}{|c|}{ Country Group } \\
\hline & LAC & Advanced & LAC & Advanced \\
\hline & \multicolumn{2}{|c|}{$h=0$} & \multicolumn{2}{|c|}{$h=2$} \\
\hline Baseline & $\begin{array}{c}-0.50 * * * \\
(0.14)\end{array}$ & $\begin{array}{c}-0.34 * * * \\
(0.11)\end{array}$ & $\begin{array}{c}-0.88 * * * \\
(0.15)\end{array}$ & $\begin{array}{c}-0.71 * * * \\
(0.18)\end{array}$ \\
\hline Trimmed sample & $\begin{array}{l}-0.50^{*} \\
(0.24)\end{array}$ & $\begin{array}{c}-0.47 * * * \\
(0.12)\end{array}$ & $\begin{array}{c}-0.84 * * * \\
(0.13)\end{array}$ & $\begin{array}{c}-0.89 * * * \\
(0.17)\end{array}$ \\
\hline $\begin{array}{l}\text { AIPW matching } \\
\text { estimator }\end{array}$ & $\begin{array}{c}-0.60 * * * \\
(0.24)\end{array}$ & $\begin{array}{c}-0.28 * * * \\
(0.09)\end{array}$ & $\begin{array}{l}-0.67 * \\
(0.44)\end{array}$ & $\begin{array}{c}-0.94^{* *} \\
(0.28)\end{array}$ \\
\hline
\end{tabular}

Notes: Country and time fixed effects included in all regressions. Driscoll-Kraay standard errors in parentheses. For the AIPW estimates empirical sandwich standard errors (clustered by country) are reported. ${ }^{*}$ Significant at $10 \%$; ${ }^{* *}$ significant at $5 \% ; * * *$ significant at $1 \%$.

\section{Sensitivity to outliers}

First, we investigate the sensitivity of the results to outliers. While especially large or small fiscal consolidations are worth considering, it is natural to ask how important they are for the results. Investigating whether unusually large fluctuations in output are driving the results is also warranted. We therefore re-estimate the baseline equation after dropping the largest and smallest 5 percent of the fiscal policy changes and real GDP growth rates from the sample. As Table 2 reports, the multiplier estimates are similar based on this trimmed sample, implying that outliers are not driving the results.

\section{The Average Treatment Effect of Consolidation based on a Matching Estimator}

One possible concern regarding consolidations identified with the narrative approach is that these episodes might be predicted by past variables. To address this concern, Jordà and Taylor (2015) propose the use of an augmented inverse propensity score weighting (AIPW) estimator. The weights used are based on the predicted component of the narrative episodes obtained from a probit model of the probability of treatment. The intuition behind this estimation strategy is that less weight is given to consolidations that are better predicted by a vector of control variables. 
To assess whether the results obtained with the matching estimator differ from our baseline, we convert the narrative fiscal shocks into a binary variable $D_{t}$ (referred to as the "fiscal treatment") that takes a value of 1 when a fiscal consolidation occurred and 0 otherwise. It is important to note that this transformation has implications for the identification of the effects of fiscal actions, since the narrative approach relies not only on the timing of fiscal adjustments but also on their size. Indeed, the loss of the latter dimension is a significant drawback of the AIPW estimator.

The first-stage probit model includes the following determinants of the probability of treatment, $p_{t}$ : past fiscal consolidations (two lags); two lags of GDP growth; the change in the commodity export price and two of its lags; the lagged debt-to-GDP ratio; lagged inflation; the lagged current account to GDP balance, lagged changes in perceived sovereign default risk; and country fixed effects. ${ }^{9}$ In an ideal randomized control trial, the distributions for the predicted probability of treatment between treatment and control groups should be identical. Annex Figure A1 presents smooth kernel density estimates of the distribution of the propensity score $\left(\hat{p}_{t}\right)$ for treated and control units. The overlap between the distributions appears to be much larger in the sample of emerging economies relative to advanced economies. Moreover, in the sample of emerging economies, the estimated probability of treatment shows relatively little mass at values close to unity.

The point estimates reported in Table 2 for the fiscal multiplier in emerging economies change little with respect to the baseline OLS results. Multipliers are slightly larger than our baseline estimates on impact (around 0.6), and reach 0.67 after two years, which is statistically indistinguishable from the baseline results. While the multiplier point estimate for advanced economies rises somewhat, the difference between the two groups remains small and not statistically different from zero.

\section{EXTENSIONS}

\section{A. The Effects of Fiscal Consolidation on Unemployment and Domestic Demand}

In this section, we examine the effects of fiscal consolidations on the unemployment rate and on private domestic demand (private investment and private consumption), employing the

\footnotetext{
${ }^{9}$ Results from the first-stage probit regression are available upon request. Lagged growth and lagged treatment have statistically significant effects in the regressions for both groups of countries (with the expected sign). Interestingly, lagged treatment presents larger marginal effects in advanced economies, implying an increase in probability of consolidation by 35 percent compared to an average marginal effect of 11 percent for emerging economies. The lagged current account balance and sovereign risk perceptions also appear as statistically significant determinants of the probability of treatment in advanced economies, but not in the sample of emerging economies. The marginal effects of these variables are small in an economic sense.
} 


\section{Figure 5. Impact of Fiscal Consolidations on Unemployment}
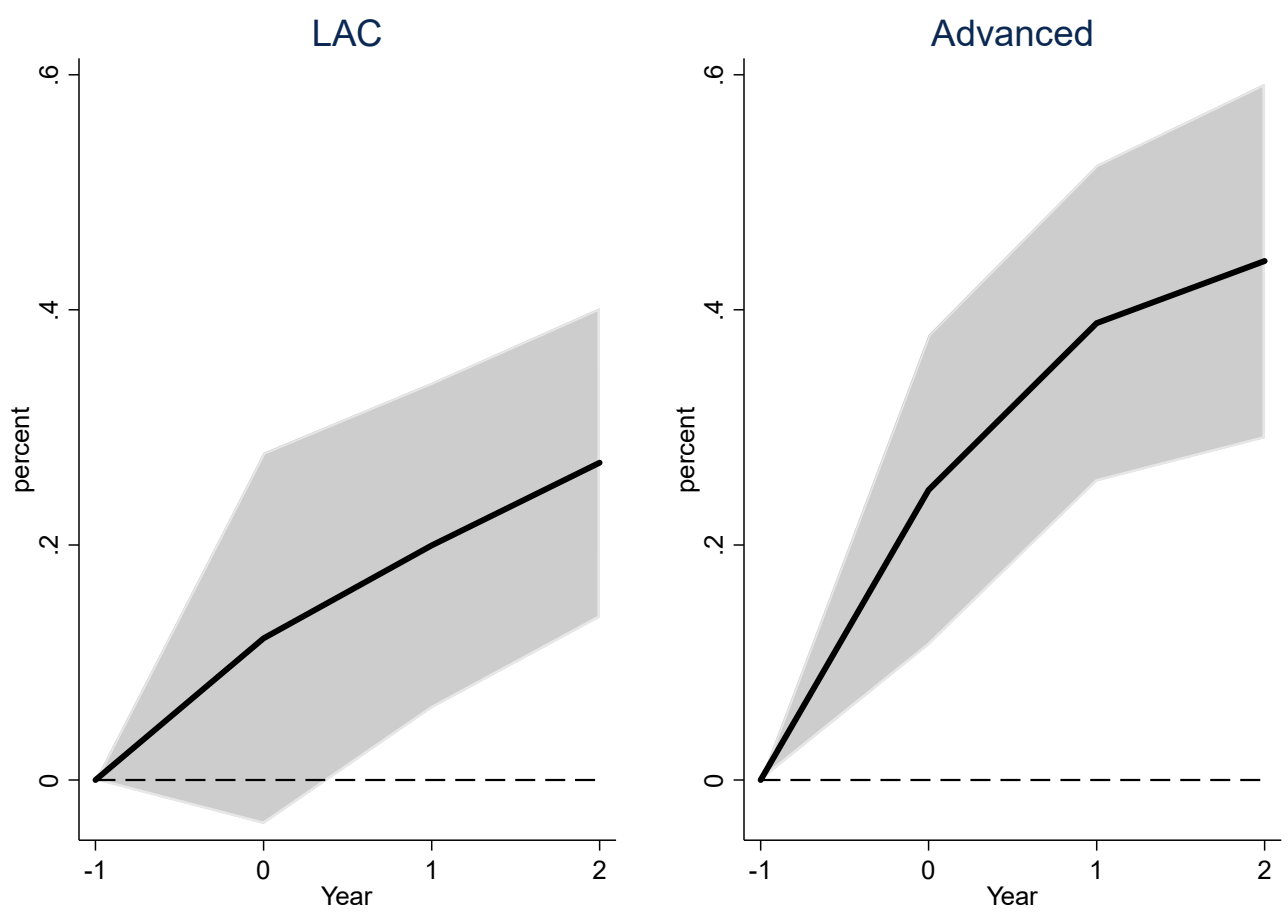

Note: Dark gray shading represents the 90 percent confidence interval.

same local projections specification used previously. ${ }^{10}$ Quantifying the effects of consolidations on private demand is particularly interesting, as the size of multipliers depends on private sector reactions to fiscal policy.

As shown in Figure 5, fiscal consolidations lead to a significant increase in the unemployment rate. Over a two-year horizon a fiscal consolidation of 1 percent of GDP leads to an increase in the unemployment rate of 0.3 percentage points in LACs, confirming the contractionary effects of consolidations. These effects are somewhat smaller than what is observed for advanced economies, where the unemployment rate multiplier reaches 0.5 at year two. The mitigated impact on unemployment in LAC may reflect the presence of a large informal sector in many countries, which offers an alternative margin of labor market adjustment following a demand shock.

\footnotetext{
${ }^{10}$ The WEO database does not contain data on unemployment for Guatemala, reducing the sample to 13 countries for these regressions.
} 
Figure 6. Impact of Fiscal Consolidations on Private Demand
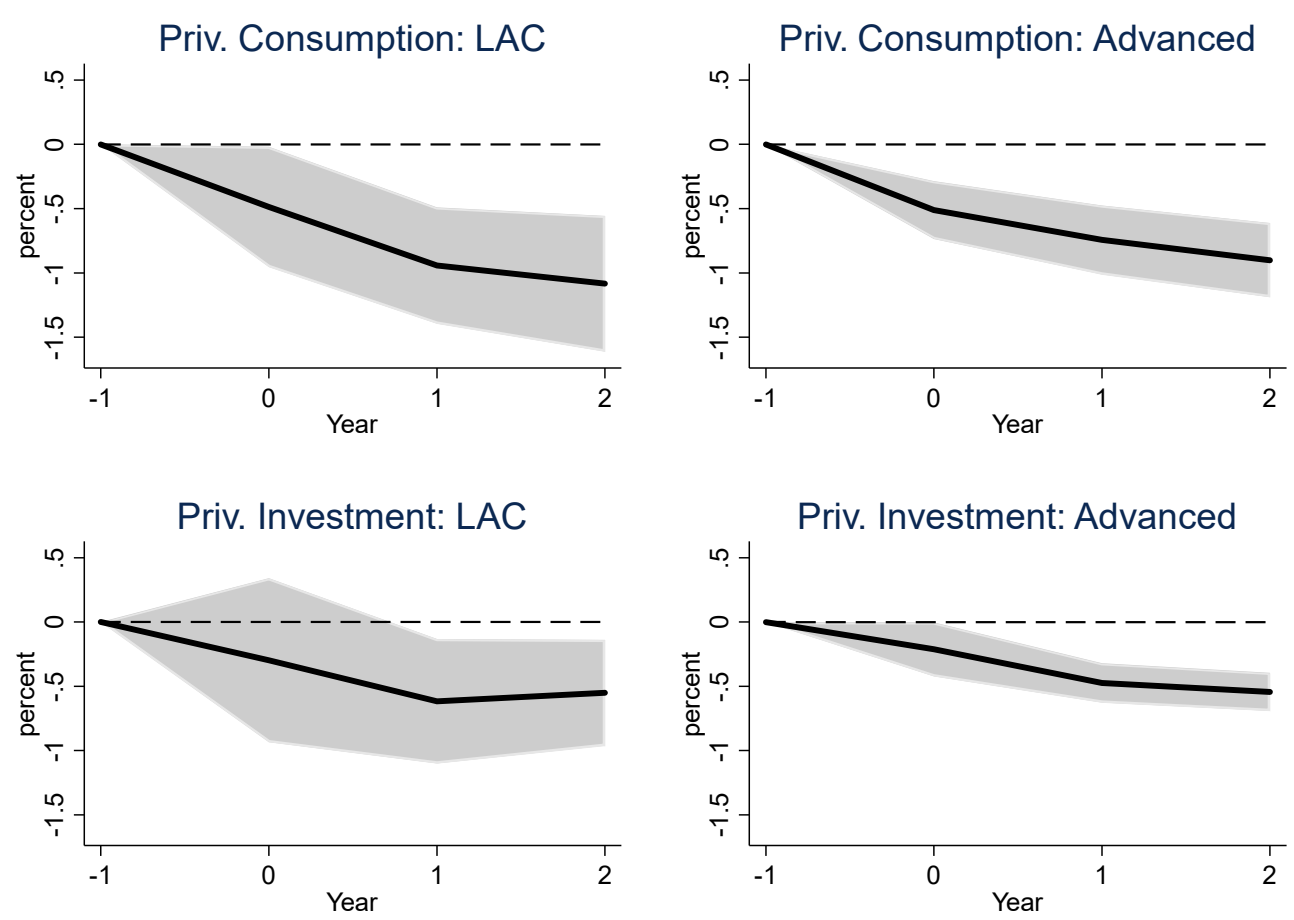

Note: Dark gray shading represents the 90 percent confidence interval.

Figure 6 reports the response of private consumption and investment following fiscal consolidations. These lead to a decline in private consumption in both country groups, with multipliers of around 1 after two years. The effects of consolidations on private investment are also similar across both groups of countries, with a multiplier reaching about 0.5 after two years. Overall, there does not seem to be any evidence of crowding-in effects of austerity measures on private demand. On the contrary, consolidations also linked to falls in private consumption and investment.

\section{B. The Effect of Consolidations on the External Current Account Balance}

An implication of many open-economy macro models with non-Ricardian features is that a fiscal consolidation would lead to a real exchange rate depreciation and would be accompanied by an improvement in the current account balance. Conversely, fiscal expansions lead to real exchange rate appreciation and a deterioration in the current account balance. Such predictions are in line with the so-called twin deficits hypothesis, which posits that fiscal consolidation can reduce external imbalances. In this section, we re-examine this issue for emerging economies by using our narrative dataset covering 14 LAC countries. 


\section{Figure 7. Impact of Fiscal Consolidations on the Current Account}
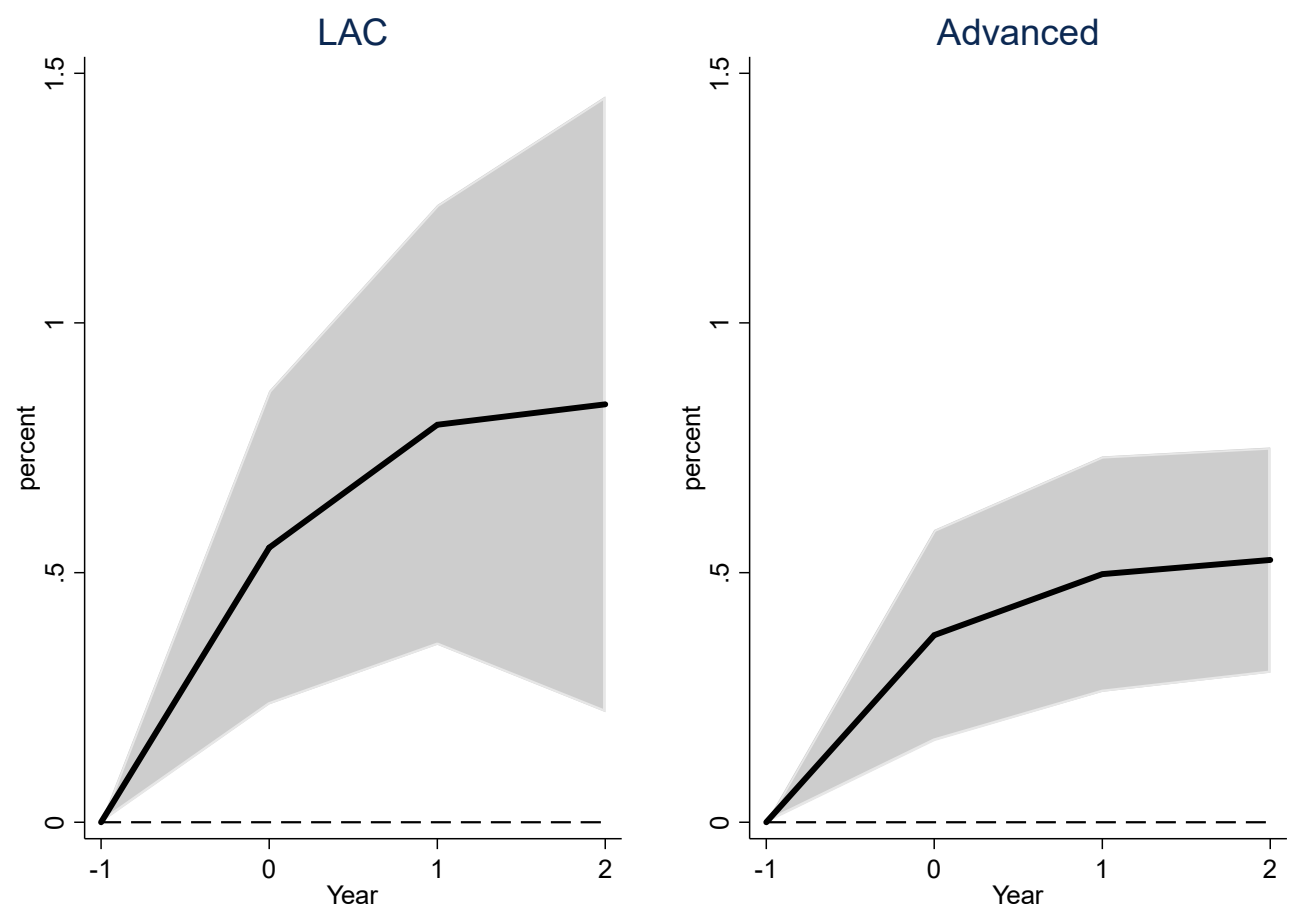

Note: Dark gray shading represents the 90 percent confidence interval.

Figure 7 presents results for the effects of consolidations on the current account to GDP ratio using the same specification used to assess the impact of consolidations on GDP and adding the changes in the commodity export price and its lagged values as control variables. We find that consolidations improve the current account balance in line with the results obtained for AEs by Bluedorn and Leigh (2011) and supporting the "twin deficits" hypothesis.

Nevertheless, the magnitude of the effects of consolidations on the current account is somewhat larger in the LAC sample relative to advanced economies. In LAC, a one percent of GDP fiscal consolidation leads to an improvement in the current account balance of around 0.8 percent of GDP after two years. For advanced economies we find an impact of around 0.5 after two years using the narrative episodes already mentioned. ${ }^{11}$

\footnotetext{
${ }^{11}$ Bluedorn and Leigh (2011) find peak responses of around 0.8 percent of GDP for a sample of advanced economies based on the Devries and others (2011) dataset.
} 
Figure 8. Impact of Fiscal Consolidations on the Real Effective Exchange Rate
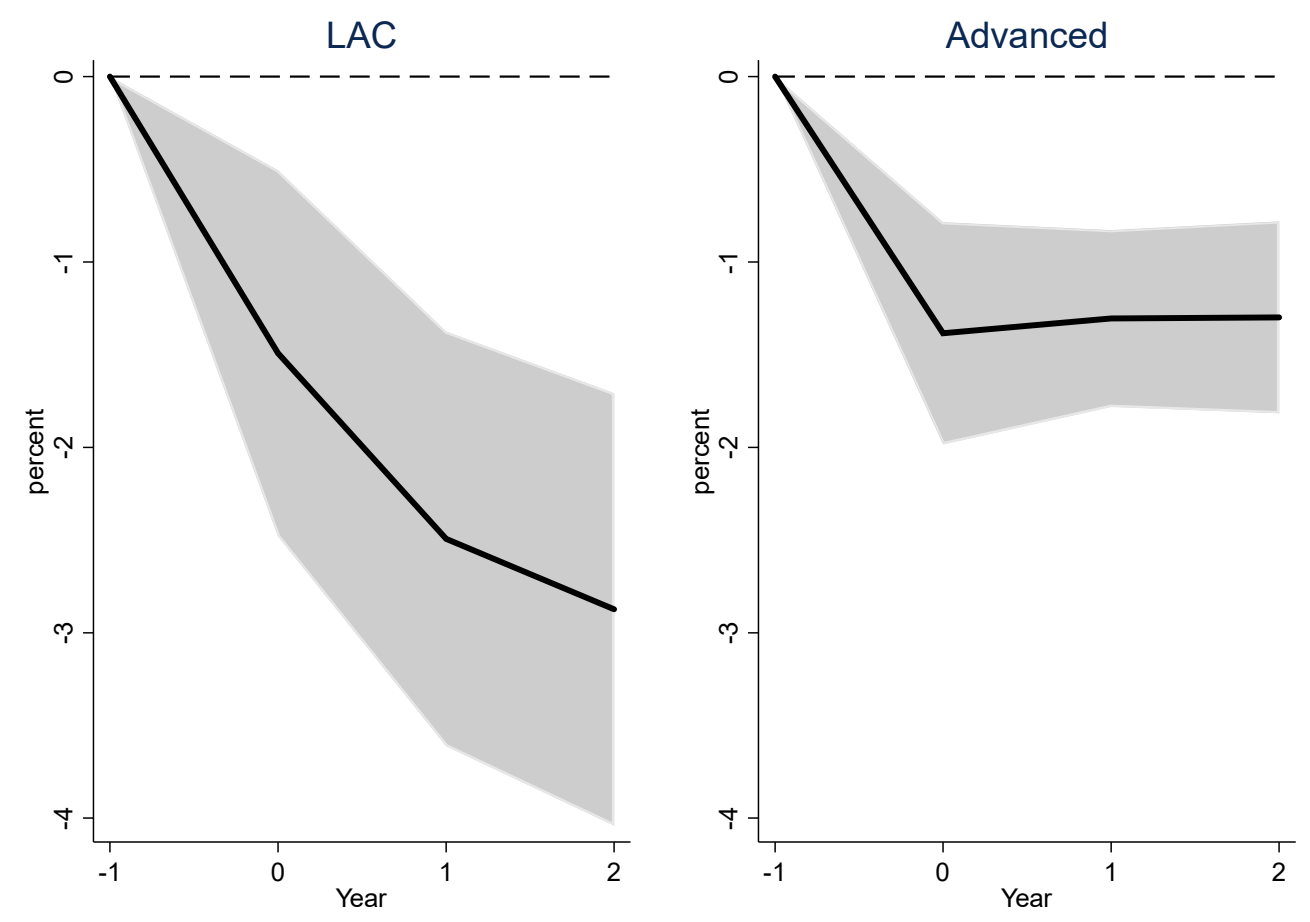

Note: Dark gray shading represents the 90 percent confidence interval.

Standard models suggest that the exchange rate is a mechanism for current account adjustment in response to fiscal policy. ${ }^{12}$ Figure 8 depicts the impact of fiscal shocks on the real effective exchange rate and support that this mechanism is at play. These specifications are similar to the baseline, but the log of the real effective exchange rate is the macroeconomic variable of interest.

We find that fiscal consolidations lead to a depreciation of the real exchange rate. The magnitude of the estimated effects is larger in the LAC sample, with an estimated depreciation of around 3 percent within two years compared to a depreciation of around 1.3 percent for AEs over the same period.

\footnotetext{
${ }^{12}$ IMF (2017) presents a useful discussion of the predictions of open economy macro models regarding the effects of fiscal policy actions on the exchange rate. While a strand of the literature implies that fiscal consolidations should lead to a depreciation of the real exchange rate, several models predict the opposite effect.
} 
Figure 9. Impact of Fiscal Consolidation on Output: Booms vs. Slumps
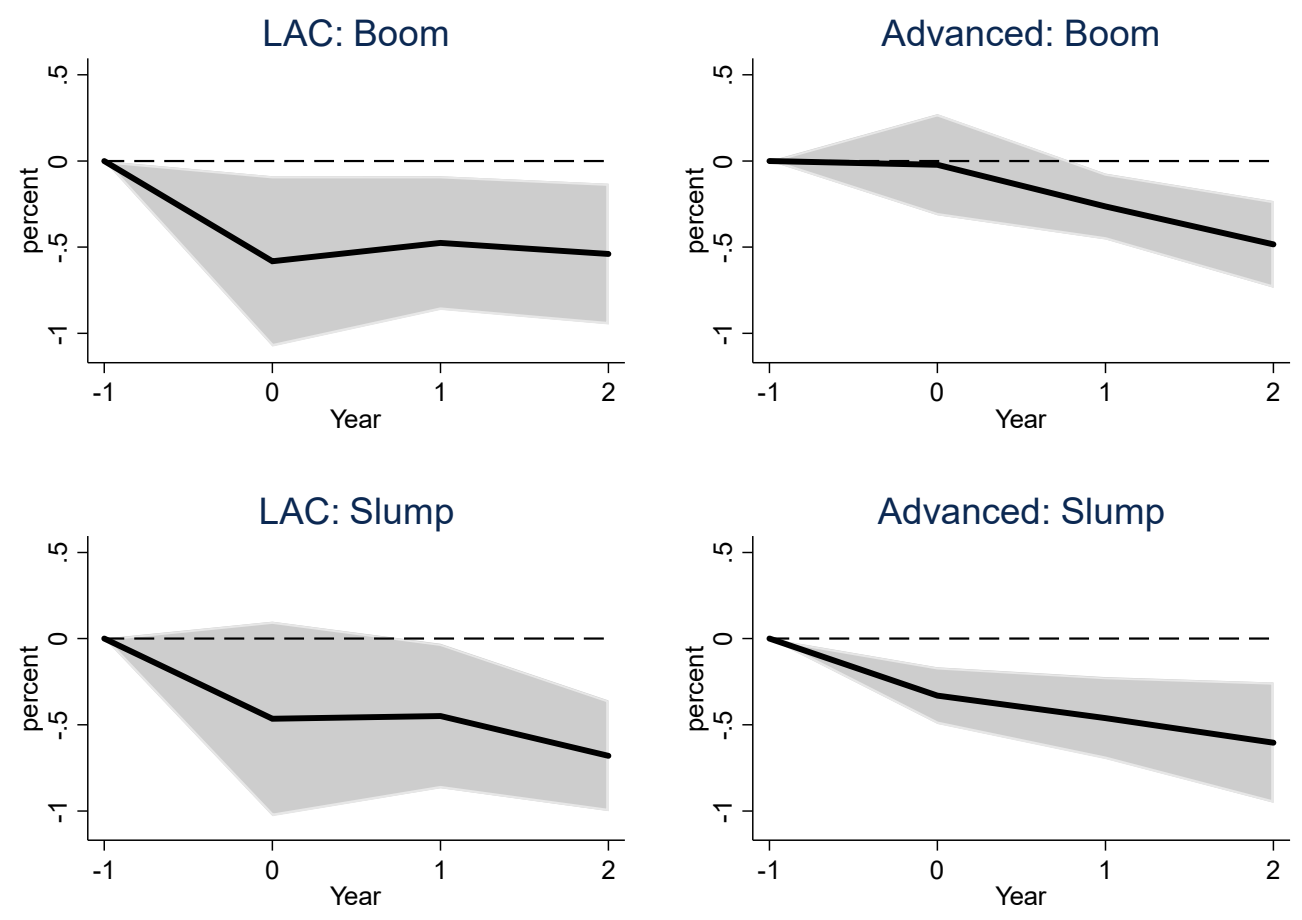

Note: Dark gray shading represents the 90 percent confidence interval.

\section{Differentiating between Booms and Slumps}

Based on traditional Keynesian models, periods of economic slack are times where there is excess capacity in the economy, and therefore less crowding out of fiscal actions, which would imply larger fiscal multipliers. Furthermore, the proportion of credit constrained agents is also likely to be higher during recessions, which would also imply higher multipliers (IMF, 2017). In addition, monetary policy reaction to fiscal actions could also be different during recessions if central banks are more likely to accommodate the impact of additional spending on demand.

There is a burgeoning empirical literature attempting to estimate how multipliers vary depending on the state of the business cycle with inconclusive results. While several studies confirm the prior that multipliers are higher if fiscal actions are preceded by recession periods (Baum, Poplawaski Ribeiro and Weber, 2012; Jordà and Taylor, 2015; Auerbach and Gorodnichenko, 2012, among others); other studies do not find such differential effects (Alesina and others, 2018; Ramey and Zubairy, 2018). 
In this sub-section, we examine whether the output effects of consolidations differ depending on the state of the business cycle. We carry out the estimation of the previous models on two bins of data depending on whether the economy is experiencing a boom (denoted by the $b$ subscript) or a slump (denoted by $r$ ):

$$
\begin{aligned}
y_{i, t+h}-y_{i, t-1}= & S_{i, t-1}\left[\alpha_{b i}^{h}+\gamma_{b t}^{h}+\beta_{b}^{h} \sum_{s=t}^{t+h} F C_{i, s}+\delta_{b} X_{i, t}\right]+\left(1-S_{i, t-1}\right)\left[\alpha_{r i}^{h}+\gamma_{r t}^{h}+\right. \\
& \left.\beta_{r}^{h} \sum_{s=t}^{t+h} F C_{i, s}+\delta_{r} X_{i, t}\right]+\varepsilon_{i, t+h} .
\end{aligned}
$$

The state indicator variable $S_{i, t-1}$ takes the values 0 or 1 depending on the sign of the output gap (obtained using the HP filter with a smoothing parameter of 6.25). ${ }^{13}$ The vector $X_{i, t}$ contains the same control variables as in previous sections.

Figure 9 shows that differentiating between booms and slumps does not seem to influence the effects of fiscal consolidations in emerging economies, with consolidations being contractionary in either case. Multiplier estimates exceed 0.5 at the two-year horizon in both states (reaching 0.7 in slumps), and remain statistically significant at the 5 percent level. Results for advanced economies also fail to uncover stark differences in multipliers across states of the business cycle, with estimates of similar magnitudes to those obtained for emerging economies.

\section{The Role of Perceived Sovereign Default Risk}

The literature suggests that fiscal consolidations could be expansionary if they help to reduce borrowing costs by dissipating doubts about the financial solvency of the government (Guajardo, Leigh and Pescatori, 2014). Therefore, one would expect that consolidations that were preceded by periods of high perceived sovereign risk could lead to smaller output losses.

To test this hypothesis, we allow our multiplier estimates to vary across two states of perceived sovereign default risk. As a proxy, we use the Institutional Investor Ratings (IIR) index that is based on assessments of sovereign risk by private sector analysts on a scale of zero to 100 (with 100 assigned to the lowest perceived sovereign default probability). We split the samples into high (low) risk if the IIR index is below (above) the median for the sample of Latin American or advanced economies.

We then re-estimate the baseline equation 1 depending on whether the consolidation was preceded by a high-risk period or a low-risk period. Figure 10 presents the results. There is no evidence that fiscal consolidations are expansionary in emerging economies. The magnitude of the impact of fiscal consolidations on GDP is somewhat larger for episodes

\footnotetext{
${ }^{13}$ The results reported here are robust to the use of the output gap estimates reported in the WEO database, which reflect the judgement of IMF country economists. Note that the average size of consolidations in slumps is higher ( 1 percent of GDP compared to 0.7 percent of GDP in booms).
} 
Figure 10. Impact of Fiscal Consolidation on Output: High vs. Low Perceived Sovereign Risk
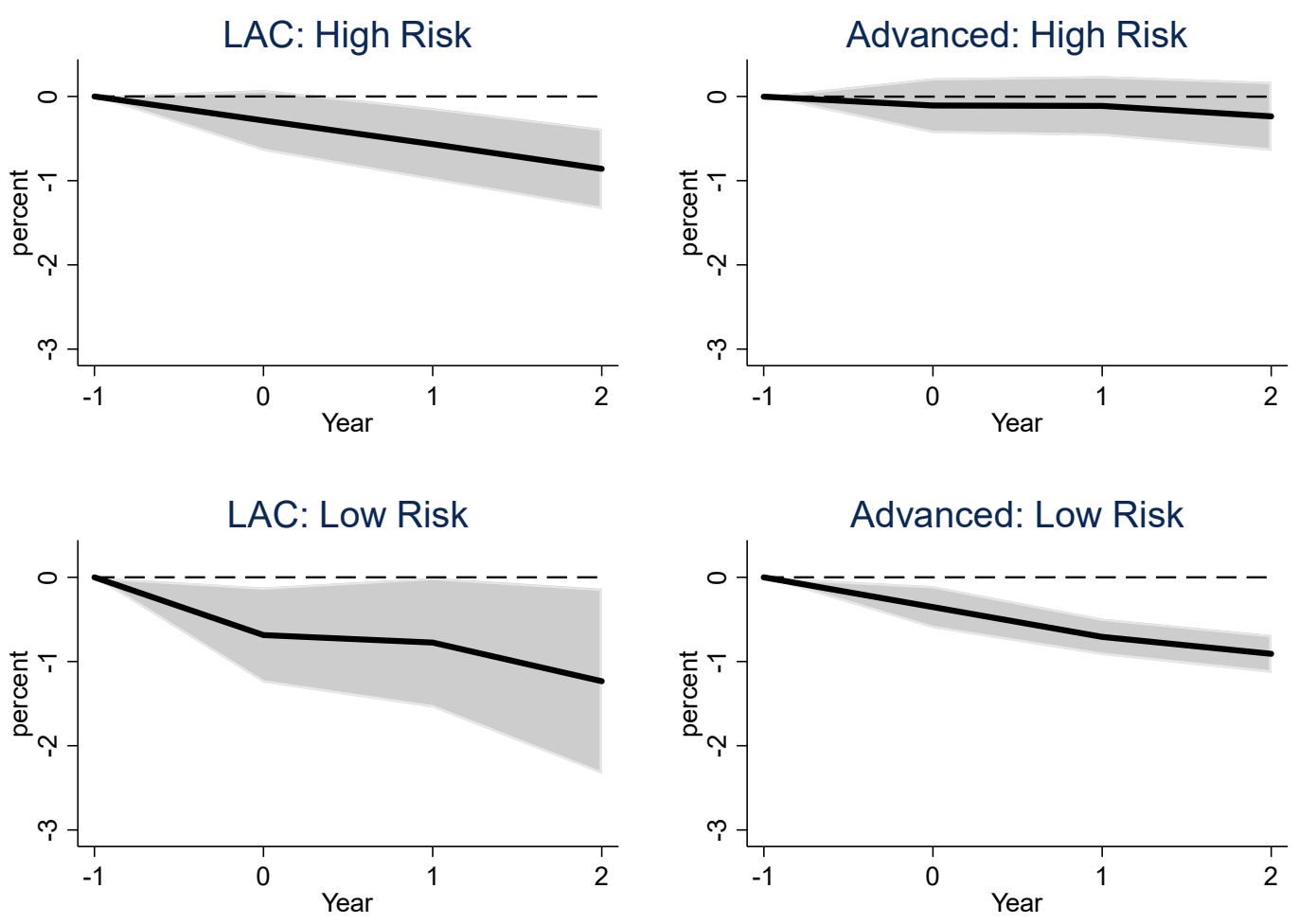

Note: Dark gray shading represents the 90 percent confidence interval.

preceded by low perceived sovereign default risk within two years (1.2 compared to around 0.9 for periods of high risk).

For the sample of advanced economies, the impact of consolidations on output is not statistically significant when they are preceded by periods of high sovereign default risk (point estimates reach 0.2 after two years), but are highly significant for periods of low risk (reaching 0.9 after two years). Overall, the finding that consolidations preceded by high sovereign risk periods entail somewhat smaller estimated output losses over the mediumterm is in line with the findings of Guajardo, Leigh and Pescatori (2014).

\section{E. Differentiating Tax-Based from Spending-Based Consolidations}

A number of studies based on data for advanced economies suggest that fiscal consolidations have smaller contractionary effects when implemented primarily through cutting government spending rather than by raising taxes. In this sub-section, we investigate this possibility for LAC economies. 
We assess the differential impact of spending-based versus tax-based consolidations by estimating the following equation, where $T B_{i, t}$ is an indicator variable that is equal to 1 when a tax-based consolidation is underway, and zero otherwise. ${ }^{14}$ The vector of control variables includes the commodity export price and its lags, as well as two lags of real GDP growth and two lags of the narrative consolidation shocks (irrespective of whether they were tax-based or spending-based):

$$
y_{i, t+h}-y_{i, t-1}=\alpha_{i}^{h}+\gamma_{t}^{h}+\left(\beta_{e}^{h}+\beta_{t}^{h} T B_{i, t}\right)\left[\sum_{s=t}^{t+h} F C_{i, s}\right]+\delta X_{i, t}+\varepsilon_{i, t+h} .
$$

Figure 11 depicts the multiplier impact of tax and spending-based consolidations on GDP. For both types of packages and country groups, consolidations are contractionary, reinforcing the results presented in previous sections. For the sample of advanced economies, we confirm that spending-based consolidations are on average less contractionary than those that are tax based. Estimated multipliers reach 1.7 after two years in the case of tax-based consolidations, but only amount to about 0.4 for spending-based consolidations over the same horizon.

For LAC economies, however, there is no significant difference between the impact of spending- and tax-based consolidations. If anything, point estimates suggest that spendingbased consolidations lead to somewhat larger declines in output after two years, with multipliers of 1.6 compared to 0.8 for tax-based consolidations. However, inference regarding the comparative size of multipliers across consolidation packages is inconclusive, since the impact of spending-based consolidations is imprecisely estimated in the sample of emerging economies. It is important to note that the average size of spending-based consolidations in the LAC sample is 1.2 percent of GDP, which is larger than the average size of tax-based consolidations ( 0.8 percent of GDP). The frequency of tax-based consolidations is also larger than spending-based consolidations in the sample of emerging economies.

Alesina and others (2017) argue that the differences in multipliers between spending and taxbased consolidations can reflect the persistence of the fiscal consolidation. Based on a New Keynesian model, they show that the size of the multiplier for government spending is decreasing in the persistence of fiscal shocks, while the multiplier for taxes is increasing in the persistence of the measures. Income taxes are modeled as an increase in labor income taxes, which distort labor market decisions by introducing a wedge between net wages and the marginal product of labor. A persistent increase in taxes makes the negative effect on labor supply more permanent, increasing the tax multiplier.

\footnotetext{
${ }^{14}$ The classification of consolidation packages into tax-based and spending-based packages was described in Section III.
} 


\section{Figure 11. Impact of Fiscal Consolidations on Output: Tax- vs. Expenditure-Based Packages}
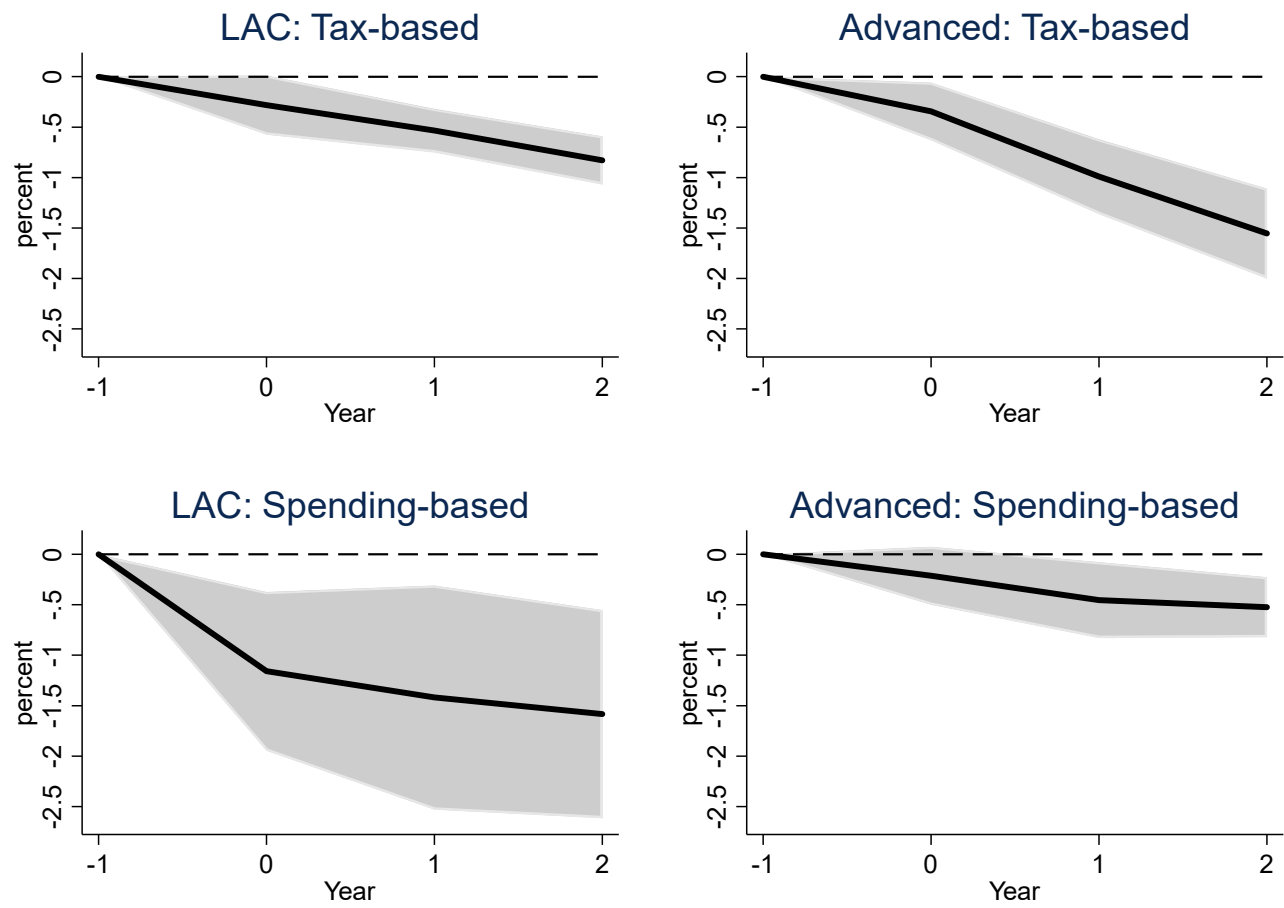

Note: Dark gray shading represents the 90 percent confidence interval.

To inform the interpretation of the similarity of our estimation results for tax and spending shocks in our LAC sample, we therefore investigate the persistence of both types of shocks. We estimate autoregressive panel models of the following form:

$$
F C_{i, t}=c_{i}+\rho_{1} F C_{i, t-1}+\rho_{2} F C_{i, t-2}+\varepsilon_{i, t}
$$

For advanced economies, we confirm the result of Alesina and others (2017) that spendingbased consolidation packages are more persistent than those that are tax-based. The sum of estimated coefficients $\rho_{1}$ and $\rho_{2}$ is 0.55 for spending-based packages ( $\mathrm{p}$-value of 0.00 ) and 0.12 for tax-based packages. For our LAC sample, however, spending-based shocks are no more persistent than tax-based ones. The sum of the coefficients $\rho_{1}$ and $\rho_{2}$ is -0.05 and 0.05 , respectively. Based on the hypothesis of Alesina and others (2017), this similarity in persistence could account for our finding of an insignificant difference between multipliers across different types of consolidation packages in LAC economies. 


\section{Conclusions}

Based on a new narrative dataset of fiscal actions, this paper concludes that fiscal consolidation is typically contractionary in the near term in LAC economies. Our estimation results are consistent with an average multiplier of 0.9 after two years for LACs, implying larger output effects than suggested by existing studies based on more conventional identification approaches. When we compare these results with near-term multipliers for advanced economies, which we estimate using comparable methods and existing narrative datasets, we find a remarkable similarity. The effects of fiscal consolidation on economic activity in advanced and emerging market economies may thus be more similar than typically assumed.

We also find that fiscal consolidation leads to a rise in the external current account balance in LAC economies, in line with a strong "twin deficits" link. The results are broadly comparable to those that we obtain for AEs. A significant depreciation in the real effective exchange rate typically accompanies the external adjustment process. In addition, we find little evidence of crowding-in effects. Private consumption and investment typically decline following fiscal consolidation, and the unemployment rate rises. However, the rise in the unemployment rate is typically smaller than for AEs, which may reflect the presence of a larger informal sector.

We find that fiscal consolidations undertaken in periods of economic booms and slumps do not have significantly different estimated effects on economic activity in LAC economies. Their effects are contractionary in both cases. We also find little evidence of differences in multipliers according to whether the composition of consolidation packages is primarily based on spending- or tax-side measures in LACs. In contrast, we do find some evidence that consolidations that are preceded by lower perceived sovereign default risk result in larger output costs. 


\section{References}

Alesina, A., O. Barbiero, C. Favero, F. Giavazzi and M. Paradisi. 2017. "The Effects of Fiscal Consolidations: Theory and Evidence,” Working paper 23385 (Cambridge, MA: National Bureau of Economic Research).

Alesina, A., G. Azzalini, C. Favero, F. Giavazzi and A. Miano. 2018. "Is it the "How" or the “'When'” that Matters in Fiscal Adjustments?” IMF Economic Review 66: 144-88.

Anós-Casero, P., D. Cardero and R. Trezzi. 2010. "Estimating the Fiscal Multiplier in Argentina," Policy Research working paper 5220 (Washington, DC: World Bank).

Auerbach, A.J. and Y. Gorodnichenko. 2012. "Measuring the Output Responses to Fiscal Policy," American Economic Journal: Economic Policy 4(2): 1-27.

Auerbach, A.J. and Y. Gorodnichenko. 2013. "Fiscal Multipliers in Recession and Expansion," in Fiscal Policy after the Financial Crisis, eds. A. Alesina and F. Giavazzi (Chicago, IL: University of Chicago Press).

Auerbach, A.J. and Y. Gorodnichenko. 2017. "Fiscal Multipliers in Japan," Research in Economics 71(3): 411-21.

Barro, R.J. and C.J. Redlick. 2011. "Macroeconomic Effects from Government Purchases and Taxes," Quarterly Journal of Economics 126: 51-102.

Batini, N., G. Callegari and G. Melina. 2012. "Successful Austerity in the United States, Europe, and Japan,” Working paper 12/190 (Washington, DC: International Monetary Fund).

Baum, A., M. Poplawaski Ribeiro and A. Weber. 2012. "Fiscal Multipliers and the State of the Economy," Working paper 12/286 (Washington, DC: International Monetary Fund).

Beetsma, R. and M. Giuliodori. 2011. "The Effects of Government Purchases Shocks: Review and Estimates for the EU," Economic Journal 121(550): F4-F32.

Blanchard, O.J. 1990. "Comment on F. Giavazzi and M. Pagano, 'Can Severe Fiscal Consolidations Be Expansionary? Tales of Two Small European Countries'," in NBER Macroeconomics Annual, Vol. 5, eds. O.J. Blanchard and S. Fischer, pp. 1116. (Cambridge, MA: National Bureau of Economic Research).

Blanchard, O.J. and R. Perotti. 2002. "An Empirical Characterization of the Dynamic Effects of Changes in Government Spending and Taxes on Output," Quarterly Journal of Economics 117(4): 1329-68. 
Bluedorn, J. and D. Leigh. 2011. "Revisiting the Twin Deficits Hypothesis: The Effect of Fiscal Consolidation on the Current Account," IMF Economic Review 59(4): 582602.

Brückner, M. and A. Tuladhar. 2010. "Public Investment as a Fiscal Stimulus: Evidence from Japan's Regional Spending During the 1990s," Working paper 10/110 (Washington, DC: International Monetary Fund).

Céspedes, L.F. and A. Velasco. 2014. "Was This Time Different? Fiscal Policy in Commodity Republics," Journal of Development Economics 106: 92-106.

Cloyne, J. 2013. "Discretionary Tax Changes and the Macroeconomy: New Narrative Evidence from the United Kingdom," American Economic Review 103(4): 1507-28.

Devries, P., J. Guajardo, D. Leigh and A. Pescatori. 2011. "A New Action-Based Dataset of Fiscal Consolidation,” Working paper 11/128 (Washington, DC: International Monetary Fund).

David, A.C. 2017. "Fiscal Policy Effectiveness in a Small Open Economy: Estimates of Tax and Spending Multipliers in Paraguay," Working paper 17/63 (Washington, DC: International Monetary Fund).

David, A.C. and D. Leigh. 2018. "A New Action-based Dataset of Fiscal Consolidation in Latin America and the Caribbean," Working paper 18/94 (Washington, DC: International Monetary Fund).

Espinoza, R. and A. Senhadji. 2011. "How Strong are Fiscal Multipliers in the GCC? An Empirical Investigation," Working paper 11/61 (Washington, DC: International Monetary Fund).

Estevao, M. and I. Samake. 2013. "The Economic Effects of Fiscal Consolidation with Debt Feedback," Working paper 13/136 (Washington, DC: International Monetary Fund).

Fernández, A., A. González and D. Rodríguez. 2018. "Sharing a Ride on the Commodities Roller Coaster: Common Factors in Business Cycles of Emerging Economies," Journal of International Economics 111: 99-121.

Fornero, J., J. Guerra-Salas and C. Perez. 2017. "Multiplicadores Fiscales en Chile,” Banco Central de Chile, mimeo.

Furceri, D. and B.G. Li, 2017. "The Macroeconomic and Distributional Effects of Public Investment in Developing Economies," Working paper 17/217 (Washington, DC: International Monetary Fund). 
Gechert, S. 2015. "What Fiscal policy is most effective? a meta regression analysis" Oxford Economic Papers 67(3): 553-80.

Gonzalez-Garcia, J., A. Lemus and M. Mrkaic. 2013. "Fiscal Multipliers in the ECCU," Working paper 13/117 (Washington, DC: International Monetary Fund).

Guajardo, J., D. Leigh and A. Pescatori. 2014. "Expansionary Austerity? International Evidence," Journal of the European Economic Association 12(4): 949-68.

Gunter, S., D. Riera-Crichton, C.A. Végh and G. Vuletin. 2017. "Non-linear effects of tax changes on output: A worldwide narrative approach,” Discussion paper IDP-DP-540 (Washington, DC: Inter-American Development Bank).

Gruss, B. 2014. "After the boom-Commodity prices and economic growth in Latin America and the Caribbean," Working paper 14/154 (Washington, DC: International Monetary Fund).

Hernández de Cos, P. and E. Moral-Benito. 2013. "Fiscal Multipliers in Turbulent Times: The Case of Spain,” Working paper 1309 (Madrid: Banco de España).

Ilzetzki, E., E. Mendoza and C.A. Végh. 2013. "How big (small?) are fiscal multipliers?" Journal of Monetary Economics 60: 239-54.

International Monetary Fund. 2017. "Cross-Border Impacts of Fiscal Policy: Still Relevant?" Chapter 4 of World Economic Outlook, October (Washington, DC: International Monetary Fund).

Jooste, C. 2012. "Analyzing the Effects of Fiscal Policy Shocks in the South African Economy," Department of Economics working paper 2012-06 (Pretoria: University of Pretoria).

Jordà, Ò. 2005. "Estimation and Inference of Impulse Responses by Local Projections," American Economic Review 95(1): 161-82.

Jordà, Ò. and A. Taylor. 2015. "The Time for Austerity: Estimating the Average Treatment Effect of Fiscal Policy," Economic Journal 126: 219-55.

Kraay, A. 2012. "How Large is the Government Spending Multiplier? Evidence from World Bank Lending," Quarterly Journal of Economics 127(2): 829-87.

Matheson, T. and J. Pereira. 2016. "Fiscal Multipliers for Brazil," Working paper 16/79 (Washington, DC: International Monetary Fund).

Mertens, K. and M.O. Ravn. 2013, "The Dynamic Effects of Personal and Corporate Income Taxes in the United States," American Economic Review 103: 1212-47. 
Mountford, A. and H. Uhlig. 2009. "What are the Effects of Fiscal Policy Shocks?" Journal of Applied Econometrics 24: 960-992.

Muir, D. and A. Weber. 2013. "Fiscal Multipliers in Bulgaria: Low but Still Relevant," Working paper 13/49 (Washington, DC: International Monetary Fund).

Nakamura, E. and J. Steinsson. 2014. "Fiscal Stimulus in a Monetary Union: Evidence from U.S. Regions," American Economic Review 104(3): 753-92.

Narita, M. 2014. "Fiscal Multipliers in the Caribbean," in Caribbean Renewal: Tackling Fiscal and Debt Challenges, eds. C. Amo-Yartey and T. Turner-Jones (Washington, DC: International Monetary Fund).

Owyang, M., V. Ramey and S. Zubairy. 2013. “Are Government Spending Multipliers Greater during Periods of Slack? Evidence from Twentieth-Century Historical Data," American Economic Review: Papers and Proceedings 103: 129-34.

Rafiq, S. and A. Zeufack. 2012. "Fiscal Multipliers over the Growth Cycle: Evidence from Malaysia,” Policy Research working paper 5982 (Washington, DC: World Bank).

Ramey, V. 2011. "Identifying Government Spending Shocks: It's All in the Timing," Quarterly Journal of Economics CXXVI: 1-50.

Ramey, V. 2016. "Macroeconomic Shocks and Their Propagation,” Working paper 21978 (Cambridge: National Bureau of Economic Research).

Ramey, V. and S. Zubairy. 2018. "Government Spending Multipliers in Good Times and in Bad: Evidence from U.S. Historical Data,” Journal of Political Economy, forthcoming.

Ravn, S.H. and M. Spange. 2012. "The effects of fiscal policy in a small open economy with a fixed exchange rate: The Case of Denmark," Working paper 80 (Copenhagen: Danmarks Nationalbank).

Riera-Crichton, D., C.A. Végh and G. Vuletin. 2016. "Tax Multipliers: Pitfalls in Measurement and Identification," Journal of Monetary Economics 79, 30-48.

Romer, C.D. and D. Romer. 2010. "The Macroeconomic Effects of Tax Changes: Estimates Based on a New Measure of Fiscal Shocks," American Economic Review 100(3): 763-801.

Šimovic, H. and M. Deskar-Škrbic. 2013, "Dynamic Effects of Fiscal Policy and Fiscal Multipliers in Croatia," Journal of Economics and Business 31: 55-78. 
Stoian, A. 2012. "The Macroeconomic Effects of Fiscal Policy in Romania," Presentation. Accessed at www.finsys.rau.ro/docs/Stoian\%20Anca.pdf.

Tang, H.C., P. Liu and E.C. Cheung. 2013. "Changing Impact of Fiscal Policy on Selected ASEAN Countries," Journal of Asian Economics 24: 103-16.

Valencia, F. 2016. "Fiscal Multipliers in Mexico," in Mexico: Selected Issues, Country report 15/314 (Washington, DC: International Monetary Fund).

Vtyurina, S. and Z. Leal. 2016. "Fiscal Multipliers and Institutions in Peru: Getting the Largest Bang for the Sol,” Working paper 16/144 (Washington, DC: International Monetary Fund).

Wang, X. and Y. Wen. 2013. "Is Government Spending a Free Lunch? Evidence from China,” Working paper 2013-013A (St. Louis, MO: Federal Reserve Bank). 
VII. ANNEXES

Table A1. Literature: Empirical Fiscal Multiplier Estimates

\begin{tabular}{|c|c|c|c|c|}
\hline Country & G & $T$ & Study & Notes \\
\hline LAC countries & 0.3 & 0.2 & & \\
\hline Argentina & 0.0 & 0.0 & Anós-Casero and others (2010) & SVAR \\
\hline Brazil & 0.5 & 0.5 & Matheson and Pereira (2016) & SVAR \\
\hline Caribbean & 0.5 & 0.6 & Narita (2014) & SVAR, 14 Caribbean countries \\
\hline Caribbean & 0.8 & . & Narita (2014) & 7 lower debt Caribbean countries \\
\hline Caribbean & 0.0 & . & Narita (2014) & 4 higher debt Caribbean countries \\
\hline Chile & 0.6 & . & Fornero, Guerra-Salas, Perez (2017) & SVAR \\
\hline Costa Rica & 0.1 & 0.0 & Estevão and Samake (2013) & SVECM \\
\hline Dominican Republic & 0.2 & 0.0 & Estevão and Samake (2013) & SVECM \\
\hline ECCU & 0.4 & 0.5 & Gonzales-Garcia and others (2013) & SVAR \\
\hline El Salvador & 0.2 & 0.0 & Estevão and Samake (2013) & SVECM \\
\hline Guatemala & 0.4 & 0.0 & Estevão and Samake (2013) & SVECM \\
\hline Honduras & 0.3 & 0.0 & Estevão and Samake (2013) & SVECM \\
\hline Mexico & 0.7 & . & Valencia (2016) & State-level panel data \\
\hline Nicaragua & 0.0 & 0.0 & Estevão and Samake (2013) & SVECM \\
\hline Panama & 0.4 & 0.0 & Estevão and Samake (2013) & SVECM \\
\hline Paraguay & 0.8 & 0.1 & David (2017) & SVAR, LPM. Average of estimates \\
\hline Paraguay & . & 1.1 & David (2017) & Narrative. Average of estimates \\
\hline Peru & 0.0 & 0.0 & Anós-Casero and others (2010) & VECM \\
\hline Peru & 0.3 & 0.2 & Vtyurina and Leal (2016) & TVAR, downturn \\
\hline Peru & 0.2 & 0.2 & Vtyurina and Leal (2016) & TVAR, upturn \\
\hline Non-LAC EMDEs & 0.6 & 0.5 & & \\
\hline Bulgaria & 0.2 & 0.4 & Muir and Weber (2013) & \\
\hline China & 2.7 & . & Wang and Wen (2013) & Government consumption \\
\hline Croatia & 0.8 & 0.6 & Simovic and Deskar-Škrbic (2013) & Central government data \\
\hline Indonesia & -0.3 & 0.4 & Tang and others (2010) & Average of different VAR specifications \\
\hline Malaysia & 0.2 & 0.4 & Tang and others (2010) & Average of different VAR specifications \\
\hline Malaysia & 2.7 & 0.1 & Rafiq and Zeufack (2012)* & Downturn \\
\hline Malaysia & 2.0 & 0.2 & Rafiq and Zeufack (2012)* & Upturn \\
\hline Philippines & 0.4 & 0.1 & Tang and others (2010) & Average of different VAR specifications \\
\hline Romania & 0.5 & 0.9 & Stoian (2012) & \\
\hline Saudi Arabia & 0.3 & . & Espinoza and Senhadji (2011) & Non-oil GDP \\
\hline Singapore & -0.2 & 0.5 & Tang and others (2010) & Average of different VAR specifications \\
\hline South Africa & 0.3 & 0.7 & Jooste (2012) & \\
\hline Thailand & -0.4 & 1.0 & Tang and others (2010) & Average of different VAR specifications \\
\hline GCC & 0.3 & & Espinoza and Senhadji (2011) IMF (2014) & Non-oil GDP \\
\hline EMDEs & . & 1.8 & Gunter and others (2016) & Narrative method, 30 EMDEs \\
\hline EMDEs & -0.1 & . & Ilzetzki, Mendoza, and Vegh (2013) & SVAR, 24 EMDES \\
\hline EMDEs & 1.6 & . & Ilzetzki, Mendoza, and Vegh (2013) & SVAR, 24 EMDEs, public invest. \\
\hline EMDEs & 0.2 & . & Furceri and Li (2017) & Public investment only \\
\hline EMs & 0.3 & 0.1 & Estevão and Samake (2013) & SVECM \\
\hline LICs & 0.2 & 0.0 & Estevão and Samake (2013) & SVECM \\
\hline LICs & 0.4 & . & Kraay (2012) & Public investment only \\
\hline
\end{tabular}

Note: $\mathrm{G}$ denotes government spending, and $\mathrm{T}$ taxes. If government consumption and investment multipliers are reported separately, the simple average of the two is reported. Table reports second-year multipliers or, when these are unavailable, impact multipliers. 
Table A1 (Continued). Literature: Empirical Fiscal Multiplier Estimates

\begin{tabular}{|c|c|c|c|c|}
\hline Country & G & $\mathbf{T}$ & Study & Notes \\
\hline AEs & 1.0 & 0.7 & & \\
\hline Canada & 1.6 & . & Owyang, Ramey, and Zubairy (2013) & Narrative method, high unemp. \\
\hline Canada & 0.4 & . & Owyang, Ramey, and Zubairy (2013) & Narrative method, low unemp. \\
\hline United States & 0.8 & . & Owyang, Ramey, and Zubairy (2013) & Narrative method, high unemp. \\
\hline United States & 0.7 & . & Owyang, Ramey, and Zubairy (2013) & Narrative method, low unemp. \\
\hline United States & 0.6 & . & Auerbach and Gorodnichenko (2012) & SVAR, expansion \\
\hline United States & 2.5 & . & Auerbach and Gorodnichenko (2012) & SVAR, recession \\
\hline United States & 0.7 & 1.1 & Barro and Redlick (2011) & Defense spending \\
\hline United States & 0.9 & 0.9 & Blanchard and Perotti (2002) & SVAR \\
\hline United States & . & 1.8 & Mertens and Ravn (2013) & Narrative method, PIT \\
\hline United States & . & 0.6 & Mertens and Ravn (2013) & Narrative method, CIT \\
\hline United States & 1.5 & . & Nakamura and Steinsson (2014) & Military procurement \\
\hline United States & 0.9 & . & Ramey (2011) & Narrative method \\
\hline United States & . & 3.1 & Romer and Romer (2010) & Narrative method \\
\hline United States & 2.2 & 0.7 & Batini, Callegari and Melina (2012) & TVAR, downturn \\
\hline United States & -0.5 & 0.7 & Batini, Callegari and Melina (2012) & TVAR, upturn \\
\hline France & 1.8 & 0.3 & Batini, Callegari and Melina (2012) & TVAR, downturn \\
\hline France & 1.9 & 0.2 & Batini, Callegari and Melina (2012) & TVAR, upturn \\
\hline Italy & 1.8 & 0.2 & Batini, Callegari and Melina (2012) & TVAR, downturn \\
\hline Italy & 0.5 & 0.1 & Batini, Callegari and Melina (2012) & TVAR, upturn \\
\hline Japan & 2.0 & 0.2 & Batini, Callegari and Melina (2012) & TVAR, downturn \\
\hline Japan & 1.1 & -0.1 & Batini, Callegari and Melina (2012) & TVAR, upturn \\
\hline Canada & . & 0.1 & Baum and others (2012) & Fiscal contraction TVAR, downturn \\
\hline Canada & . & -0.2 & Baum and others (2012) & Fiscal contraction TVAR, upturn \\
\hline Germany & 1.2 & 0.3 & Baum and others (2012) & Fiscal contraction TVAR, downturn \\
\hline Germany & 0.2 & 0.4 & Baum and others (2012) & Fiscal contraction TVAR, upturn \\
\hline United Kingdom & 0.1 & . & Baum and others (2012) & Fiscal contraction TVAR, downturn \\
\hline United Kingdom & 0.0 & . & Baum and others (2012) & Fiscal contraction TVAR, upturn \\
\hline France & . & -0.5 & Baum and others (2012) & Fiscal contraction TVAR, downturn \\
\hline France & . & -0.4 & Baum and others (2012) & Fiscal contraction TVAR, upturn \\
\hline Japan & 2.0 & 0.6 & Baum and others (2012) & Fiscal contraction TVAR, downturn \\
\hline Japan & 1.7 & -0.5 & Baum and others (2012) & Fiscal contraction TVAR, upturn \\
\hline United States & 1.3 & . & Baum and others (2012) & Fiscal contraction TVAR, downturn \\
\hline United States & 1.0 & . & Baum and others (2012) & Fiscal contraction TVAR, upturn \\
\hline Japan & 2.0 & . & Auerbach and Gorodnichenko (2017) & LP method, recession \\
\hline Japan & -0.2 & . & Auerbach and Gorodnichenko (2017) & LP method, expansion \\
\hline Japan & 0.7 & . & Brückner and Tuladhar (2010) & Dynamic panel, public investment \\
\hline Japan & 0.5 & . & Brückner and Tuladhar (2010) & Dynamic panel, all expneditures \\
\hline United Kingdom & . & 2.5 & Cloyne (2013) & Narrative method \\
\hline Spain & 1.3 & . & Hernández de Cos and Moral-Benito (2013) & TVAR, crisis times \\
\hline Spain & 0.6 & . & Hernández de Cos and Moral-Benito (2013) & TVAR, tranquil times \\
\hline Denmark & 1.3 & 0.8 & Ravn and Spange (2012) & SVAR \\
\hline EU countries & 0.9 & . & Beetsma and Giuliodori (2011) & SVAR, open economies \\
\hline EU countries & 1.6 & . & Beetsma and Giuliodori (2011) & SVAR, closed economies \\
\hline AEs & . & 2.1 & Gunter and others (2016) & Narrative method, $21 \mathrm{AEs}$ \\
\hline AEs & 0.9 & . & Ilzetzki, Mendoza, and Vegh (2013) & SVAR, 20 AES \\
\hline OECD & 1.0 & 3.1 & Guanardo, Leigh, and Pescatori (2014) & Narrative method, 17 OECD \\
\hline OECD & 0.3 & 1.1 & Alesina and others (2017) & Narrative method, 17 OECD \\
\hline
\end{tabular}

Note: SVECM denotes structural vector error correction model; TVAR denotes threshold vector autoregression; LPM denotes local projection method. *G denotes government investment only. Narita (2014) study identifies higher debt Caribbean economies as ATG, GRD, KNA and JAM. 
Table A2. Budgetary Impact of Narrative Fiscal Shocks (Percent of GDP)

\begin{tabular}{|c|c|c|c|c|}
\hline Country & Year & Total & Tax & Spend \\
\hline ARG & 1996 & 0.25 & 0.25 & 0.00 \\
\hline ARG & 1997 & 0.75 & 0.75 & 0.00 \\
\hline $\mathrm{BOL}$ & 1995 & 0.90 & 0.90 & 0.00 \\
\hline $\mathrm{BOL}$ & 2004 & 2.00 & 2.00 & 0.00 \\
\hline $\mathrm{BOL}$ & 2005 & 4.10 & 4.10 & 0.00 \\
\hline BRA & 2015 & 0.80 & 0.30 & 0.50 \\
\hline $\mathrm{CHL}$ & 1990 & 0.50 & 0.50 & 0.00 \\
\hline $\mathrm{CHL}$ & 1991 & 0.17 & 0.17 & 0.00 \\
\hline $\mathrm{CHL}$ & 2003 & 0.60 & 0.20 & 0.40 \\
\hline $\mathrm{CHL}$ & 2004 & 0.40 & 0.40 & 0.00 \\
\hline $\mathrm{CHL}$ & 2008 & -0.50 & 0.00 & -0.50 \\
\hline $\mathrm{CHL}$ & 2014 & 0.10 & 0.10 & 0.00 \\
\hline $\mathrm{CHL}$ & 2015 & 0.18 & 0.18 & 0.00 \\
\hline $\mathrm{CHL}$ & 2016 & 0.31 & 0.31 & 0.00 \\
\hline $\mathrm{COL}$ & 2000 & 0.90 & 0.00 & 0.90 \\
\hline $\mathrm{COL}$ & 2003 & 1.10 & 1.10 & 0.00 \\
\hline $\mathrm{COL}$ & 2011 & 0.40 & 0.40 & 0.00 \\
\hline $\mathrm{COL}$ & 2012 & 0.80 & 0.80 & 0.00 \\
\hline $\mathrm{COL}$ & 2015 & 0.50 & 0.00 & 0.50 \\
\hline $\mathrm{COL}$ & 2016 & 0.70 & 0.00 & 0.70 \\
\hline CRI & 1990 & 1.50 & 1.50 & 0.00 \\
\hline CRI & 1991 & 3.10 & 3.10 & 0.00 \\
\hline CRI & 1992 & 0.50 & 0.50 & 0.00 \\
\hline CRI & 1993 & -0.30 & -0.30 & 0.00 \\
\hline CRI & 1994 & -0.50 & -0.50 & 0.00 \\
\hline CRI & 1995 & 1.80 & 1.00 & 0.80 \\
\hline CRI & 1996 & 0.30 & 0.30 & 0.00 \\
\hline CRI & 1997 & 0.40 & 0.00 & 0.40 \\
\hline CRI & 2016 & 0.40 & 0.20 & 0.20 \\
\hline DOM & 2004 & 1.70 & 0.50 & 1.20 \\
\hline DOM & 2006 & -0.80 & -0.80 & 0.00 \\
\hline DOM & 2007 & 0.90 & 0.90 & 0.00 \\
\hline DOM & 2011 & 0.64 & 0.44 & 0.20 \\
\hline DOM & 2013 & 3.80 & 1.80 & 2.00 \\
\hline ECU & 1990 & 0.32 & 0.32 & 0.00 \\
\hline ECU & 1993 & 2.20 & 1.70 & 0.50 \\
\hline ECU & 2000 & 0.50 & 0.50 & 0.00 \\
\hline
\end{tabular}

Note: Table records budgetary impact of narrative fiscal shocks. $\mathrm{ARG}=$ Argentina, $\mathrm{BOL}=$ Bolivia, $\mathrm{BRA}=$ Brazil, $\mathrm{CHL}=$ Chile, $\mathrm{COL}=$ Colombia, $\mathrm{CRI}=$ Costa Rica, $\mathrm{DOM}=$ Dominican Republic, $\mathrm{ECU}=$ Ecuador. 
Table A2 (continued).

Budgetary Impact of Narrative Fiscal Shocks (Percent of GDP)

\begin{tabular}{|c|c|c|c|c|}
\hline Country & Year & Total & Tax & Spend \\
\hline GTM & 1995 & 0.80 & 0.80 & 0.00 \\
\hline GTM & 1996 & 0.70 & 0.70 & 0.00 \\
\hline GTM & 2000 & 1.30 & 0.30 & 1.00 \\
\hline GTM & 2002 & 1.90 & 1.00 & 0.90 \\
\hline GTM & 2012 & 0.40 & 0.00 & 0.40 \\
\hline GTM & 2013 & 1.00 & 1.00 & 0.00 \\
\hline MEX & 1989 & 0.90 & 0.90 & 0.00 \\
\hline MEX & 2010 & 0.60 & 0.60 & 0.00 \\
\hline MEX & 2014 & 0.60 & 0.60 & 0.00 \\
\hline PRY & 1989 & 2.60 & 2.00 & 0.60 \\
\hline PRY & 2001 & 1.80 & 0.50 & 1.30 \\
\hline PRY & 2003 & 1.25 & 1.25 & 0.00 \\
\hline PRY & 2004 & 0.80 & 0.80 & 0.00 \\
\hline PRY & 2005 & -0.60 & -0.60 & 0.00 \\
\hline PRY & 2006 & -0.70 & -0.70 & 0.00 \\
\hline PRY & 2014 & 0.24 & 0.24 & 0.00 \\
\hline PRY & 2016 & 0.80 & 0.00 & 0.80 \\
\hline PER & 1992 & 1.00 & 1.00 & 0.00 \\
\hline PER & 2002 & 0.20 & 0.20 & 0.00 \\
\hline PER & 2003 & 0.80 & 0.80 & 0.00 \\
\hline PER & 2011 & -0.38 & -0.38 & 0.00 \\
\hline PER & 2012 & 0.38 & 0.38 & 0.00 \\
\hline URY & 1990 & 1.70 & 1.70 & 0.00 \\
\hline URY & 1995 & 1.65 & 0.75 & 0.90 \\
\hline URY & 1996 & 0.25 & 0.25 & 0.00 \\
\hline URY & 2000 & 0.80 & 0.00 & 0.80 \\
\hline URY & 2002 & 3.27 & 1.58 & 1.70 \\
\hline URY & 2003 & 1.63 & 1.42 & 0.20 \\
\hline URY & 2004 & -0.50 & -0.50 & 0.00 \\
\hline URY & 2005 & -0.90 & -0.90 & 0.00 \\
\hline URY & 2015 & 0.60 & 0.00 & 0.60 \\
\hline JAM & 1992 & 2.10 & 2.10 & 0.00 \\
\hline JAM & 1999 & 0.70 & 0.00 & 0.70 \\
\hline JAM & 2000 & 1.80 & 0.00 & 1.80 \\
\hline JAM & 2003 & 3.00 & 1.50 & 1.50 \\
\hline JAM & 2004 & 1.00 & 0.50 & 0.50 \\
\hline JAM & 2012 & 0.80 & 0.80 & 0.00 \\
\hline JAM & 2013 & 2.60 & 2.00 & 0.60 \\
\hline JAM & 2014 & 0.60 & 0.40 & 0.20 \\
\hline
\end{tabular}

Note: GTM $=$ Guatemala, MEX $=$ Mexico, PRY $=$ Paraguay, PER $=$ Peru, URY = Uruguay, $\mathrm{JAM}=$ Jamaica.

CInternational Monetary Fund. Not for Redistribution 
Table A3. Variable Definitions and Sources

\begin{tabular}{|c|c|c|}
\hline Variable & Definition & Source \\
\hline Real GDP & Log of real GDP in local currency. & $\begin{array}{l}\text { WEO database } \\
\text { (October } 2017 \\
\text { published vintage). }\end{array}$ \\
\hline $\begin{array}{l}\text { Real Private Investment and } \\
\text { Consumption }\end{array}$ & Log of real values in local currency. & $\begin{array}{l}\text { WEO database } \\
\text { (October } 2017 \\
\text { published vintage). }\end{array}$ \\
\hline Current Account to GDP Ratio & & $\begin{array}{l}\text { WEO database } \\
\text { (October } 2017 \\
\text { published vintage). }\end{array}$ \\
\hline Unemployment rate & & $\begin{array}{l}\text { WEO database } \\
\text { (October } 2017 \\
\text { published vintage). }\end{array}$ \\
\hline $\begin{array}{l}\text { Narrative Fiscal } \\
\text { Consolidations. }\end{array}$ & $\begin{array}{l}\text { Elaborated by the authors based on } \\
\text { contemporaneous reports and budget } \\
\text { documents. }\end{array}$ & $\begin{array}{l}\text { David and Leigh } \\
\text { (2018). }\end{array}$ \\
\hline $\begin{array}{l}\text { Cyclically Adjusted Primary } \\
\text { Balance. }\end{array}$ & $\begin{array}{l}\text { Cyclical adjustment based on WEO } \\
\text { data follows standard IMF approach } \\
\text { (see annex). }\end{array}$ & $\begin{array}{l}\text { Authors' calculations } \\
\text { based on WEO } \\
\text { database. }\end{array}$ \\
\hline Commodity Export Value & $\begin{array}{l}\text { Calculated using trade data on } 33 \\
\text { commodities. }\end{array}$ & Gruss (2014) \\
\hline Real Effective Exchange Rae & $\begin{array}{l}\text { Change in the Log of the real effective } \\
\text { exchange rate index }(2010=100) \times 100 \text {. }\end{array}$ & $\begin{array}{l}\text { WEO database } \\
\text { (October } 2017 \\
\text { published vintage). }\end{array}$ \\
\hline Debt to GDP Ratio & & $\begin{array}{l}\text { IMF FAD Historical } \\
\text { Debt Database. }\end{array}$ \\
\hline Output Gap & $\begin{array}{l}\text { Cyclical component of real GDP using } \\
\text { the HP filter with smoothing parameter } \\
\text { of } 6.25 \text {. }\end{array}$ & $\begin{array}{l}\text { Authors' calculations } \\
\text { based on WEO } \\
\text { database }\end{array}$ \\
\hline $\begin{array}{l}\text { Perceived Sovereign Default } \\
\text { Risk }\end{array}$ & Institutional Investor Ratings index. & $\begin{array}{l}\text { Institutional Investor } \\
\text { LLC }\end{array}$ \\
\hline
\end{tabular}




\section{Annex. Comparison of Narrative Deficit-driven Shocks and CAPB}

This annex focuses on the largest discrepancies between episodes identified by our narrative approach and consolidations identified using changes in the CAPB. We examine 16 cases for which the discrepancy between the two approaches exceeds 2.5 percent of GDP. We describe each of these cases and explain how we assess which methodology provides a more accurate measure of deficit-driven fiscal consolidation. In all but two of these cases-Jamaica (1992) and Chile (2008) - the increase in CAPB is larger than deficit-driven fiscal consolidation identified based on the historical policy record.

The source of our data for the CAPB is the October 2017 IMF World Economic Outlook (WEO) database. Estimates of the CAPB are not available in the WEO database in a number of cases for our 1989-2016 sample of 14 LAC economies. We therefore construct a measure of the CAPB for our sample based on the conventional procedures (Escolano, 2010). ${ }^{15}$

Argentina (2002). The CAPB improved by about 3.7 percent of GDP, but the record shows little evidence of an action-based fiscal consolidation motivated by deficit reduction. Instead, policy measures were taken in response to a sharp financial crisis and recession. The currency board arrangement was abandoned in January 2002, a moratorium on public debt service payments was imposed, along with a bank deposit freeze, exchange controls, and export surrender requirements. As to the improvement in the CAPB, the 2002 Article IV consultation staff report (EBS/02/214) states (p. 10) that the fiscal position of the federal government improved on a cash basis, reflecting a revised revenue sharing agreement with the provinces, which led to a fall in transfers in real terms, tight control of primary spending (especially wages), and sharply reduced cash interest payments. The report also explains, however, that there were large expenditures not captured in the cash balance, including: “... the issuance of $A r g \$ 36$ billion of bonds in connection with the banking crisis and additional bonds issued in recognition of other obligations incurred; interest capitalization of Arg\$26.4 billion associated with the phase one debt exchange and the indexation of government bonds; and interest arrears on phase two debt. A comprehensive measure would bring the augmented primary and overall deficits of the consolidated public sector in 2002 to 11 percent and 25 percent of GDP, respectively." Specific economic and budgetary developments thus explain why the CAPB-based measure inaccurately identifies the size of the deficit-driven consolidation.

\footnotetext{
${ }^{15}$ This measure of the CAPB is closely correlated to the reported in the WEO for countries in our sample for which the CAPB is available in the WEO. The correlation coefficient is 0.9 . The conventional approach we use consists of adjusting government revenues using an elasticity of 1 for the output gap (estimated based on real GDP data and an HP filter with a smoothing parameter of 6.25). The GDP deflator is then used to express the adjusted series in nominal terms. Subsequently the adjusted primary balance is obtained by subtracting interest revenue and primary expenditure from the adjusted revenue series and dividing it by nominal GDP.
} 
Bolivia (1994). The CAPB improved by close to 3 percent of GDP, but this reflected fiscal action to reduce inflation and rebuild international reserves. The 1994 Article IV consultation staff report (EBS/94/228) outlines the motivations for the policy actions as follows (p. 2): "The Government's economic program that was framed at the beginning of 1994 aimed to reduce inflation to 7.5 percent during the year and to increase net international reserves by US\$20 million; real GDP was assumed to grow by 4 percent. The fiscal program envisaged a reduction of the combined public sector deficit to 3 percent of GDP, mainly on the basis of a reduction in the public sector wage bill and low-priority capital expenditure." Nevertheless, as shown on Table 7 (p. 14) and Table 8 (p. 16) of the 1996 Recent Economic Developments report (SM/96/61) overall expenditure for the public sector only fell by about 0.2 percent of GDP. Most of the narrowing of the primary deficit (of about 3 percent of GDP) reflected increases in revenues (notably an increase in foreign grants of 1 percent of GDP and an improvement in tax revenues of 0.6 percent of GDP). Overall, since the rise in the CAPB reflected an anti-inflation motivation, we do not classify 1994 as an episode of fiscal consolidation motivated by deficit reduction. Specific economic and budgetary developments largely explain the gap between the two measures.

Bolivia (2006). The CAPB improved by over 6 percent of GDP, but the policy record shows no evidence of an action-based fiscal consolidation motivated by deficit reduction. A large part of the improvement in the CAPB reflected higher hydrocarbon revenues in a context of favorable international prices. According to Table 15 on page 43 of the 2006 Memoria Fiscal report produced by the Ministry of Finance, royalties related to oil and gas production (IDH) increased by 3 percent of GDP in 2006. This commodity price increase occurred at the same time as a decree of nationalization of the hydrocarbons sector was issued. The 2006 Article IV staff report (IMF Country Report No. 06/270) confirms (p. 9) the role played by commodity prices in the changes in the primary balance: “(...) this surplus reflected mostly strong hydrocarbons-based revenue associated with high oil and gas prices." Specific economic developments thus explain why the CAPB-based measure inaccurately identifies the size of the consolidation and largely explains the gap between the two measures.

Chile (2008). The policy record indicates a fiscal easing of 0.5 percent of GDP linked to the reduction in the structural target of the fiscal rule, while the CAPB fell by 4 percent of GDP based on our calculations, implying a discrepancy of 3.5 percent of GDP. ${ }^{16}$ The motivation for the reduction in the structural balance target was driven by long-run considerations, as discussed in David and Leigh (2018), namely the reduction in fiscal risks that justified the original target. The Chilean authorities' estimates presented on Table I.10 (p. 21) of the 2010 Informe de Finanzas Publicas (IFP) point to an effective (rather than targeted) deterioration in the structural balance as a share of GDP of 0.3 percent from 2007 to 2008, which is closer to the one presented by the narrative approach. We conclude that the change in the CAPB

\footnotetext{
${ }^{16}$ Calculations by the country desk presented in the WEO database also point to a decrease in the cyclicallyadjusted primary balance of over 4 percent of GDP.
} 
does not accurately identify the size of the fiscal easing, and that this explains the gap between the two measures.

Chile (2010). The CAPB improved by about 3.8 percent of GDP, but this reflected the end of one-off fiscal stimulus motivated by a response to the economic outlook in the previous year. As the 2010 Article IV consultation staff report (SM/10/230) explains (p. 4), on the expenditure side, the rise in the primary balance reflected the end of temporary stimulus measures adopted in 2009 in response to the economic downturn. On the revenue side, the rise in the primary balance reflected temporary taxes to finance reconstruction efforts following the February 2010 earthquake. In addition, estimates using a new formula for structural adjustment presented on graph b.3 on page 25 of the 2016 IFP point to an improvement in the structural balance of about 1 percent of GDP, which implies a smaller discrepancy relative to the narrative record than is implied by the CAPB. Overall, the discrepancy between the CAPB and our narrative measure reflects the fact that the CAPB picked up the effect of fiscal actions in response to the economic outlook.

Costa Rica (1994). The narrative record indicates a fiscal easing of 0.5 percent of GDP while the CAPB falls by 3.1 percent of GDP, implying a discrepancy of 2.6 percent of GDP (3.1-0.5). Sales taxes were increased temporarily as part of the 1991 revenue package discussed in detail in David and Leigh (2018) with the objective of reducing the deficit as a continuation of the program that started in 1990. The 1994 Article IV consultation staff report (SM/94/273) explains (p.2) that: "The sales tax rate was reduced gradually from 13 percent in 1991 to 10 percent in January 1994, resulting in a total revenue loss of some 1.5 percent of GDP by end-1994". Given the estimated revenue loss of 1.5 percent of GDP over three years, we assign a value of 0.5 percent of GDP to calendar year 1994. However, the report also explains that revenues fell due to a fall in imports. Moreover, there was also an increase in transfers to support the finances of the electricity company, which experienced higher generation costs due to a drought. Because these factors reflected a response to economic conditions, we do not include them in our measure of narrative fiscal shocks, and this largely explains the gap between our narrative measure and the change in the CAPB.

Dominican Republic (2015). The CAPB rose by 2.8 percent of GDP, but the policy record shows no evidence of an action-based fiscal consolidation, implying a discrepancy of 2.8 percent of GDP. The rise in the CAPB mostly reflects a capital grant from the restructuring of Petrocaribe debt (p. 7, 2015 Article IV consultation staff report, IMF Country Report No. 16/342). The 2017 Article IV consultation staff report (IMF Country Report No. 17/254) explains further in footnote 3 (p. 6) that: "The gains from the 2015 restructuring of the country's debt under the Petrocaribe arrangement with Venezuela, bought back at a discount of over 50 percent, are recorded as an above-the-line capital grant in 2015 (3 percent of GDP), boosting the headline fiscal balance for that year." See also page 16 of the 2016 Informe Explicativo y Politica Presupostaria report. A specific financial operation thus explains the gap between the two measures. 
Ecuador (1999). The CAPB improved by 4.5 percent of GDP, but the policy record shows no evidence of an action-based fiscal consolidation. 1999 was marked by a domestic financial crisis and the inability of the country to access international financial markets forcing a sharp fiscal adjustment due to the fall in oil-related revenues and a lack of financing. Output fell by 8 percent according to the 2000 SBA request report (EBS/00/66). Page 7 of the same report discusses reasons for the improvement in the primary balance: "The NFPS deficit narrowed only slightly to 6 percent of GDP in 1999, but the primary balance shifted from a deficit of 1.2 percent of GDP to a surplus of 4 percent. Oil revenues recovered sharply with the increase in world oil prices from mid-1999, and tax revenues increased by 1.3 percentage point of GDP mainly as a result of the increase in the import tariff surcharge, buoyant revenue from the financial transactions tax introduced at the start of the year, and improved tax collections. Non-interest expenditures of the NFPS remained broadly unchanged in relation to GDP (...)". Box 1 of the report presents a chronology of fiscal measures over the period 1998-1999. In February 1999, the import tariff surcharge was raised to a range between 2 and 10 percent by executive decree. In addition, a budget introducing a one percent financial transactions tax was passed by congress. The financial transactions tax rate was later reduced to 0.8 percent as part of a tax package in October. The revenues linked to the import tariff surcharge are estimated at 1 percent of GDP on an annual basis (see page 20 of the 2000 SBA request report, EBS/00/66). Note that both taxes were abolished in early 2001 without other compensating measures. Box 2 of the report presents estimates of the impact of eliminating the financial transactions tax at a loss of 0.8 percent of GDP and in the case of import surcharge the loss would be 1.2 percent of GDP.

Therefore, the two tax measures (increase in import surcharge and introduction of the financial transactions tax) with an estimated impact of around 1.3 percent of GDP in 1999 seem to have been motivated by endogenous considerations (fall in oil prices in 1998, lack of external financing). In addition, a significant part of the improvement in the primary balance is due to higher oil-related revenues in the second half of the year. Note that our measure of the CAPB only adjust for the output gap and not specifically for movements in oil prices. Table 4 on page 45 of the 2000 article IV consultation staff report (EBS/00/164) indicates that petroleum revenue increased by 2.9 percent of GDP in 1999, whereas non-petroleum revenue increased by 0.9 percent of GDP and primary expenditures fell by 0.4 percent of GDP. It appears therefore that a large part of the discrepancy between the different measures (narrative vs. CAPB) is explained by factors that were justifiably excluded from the narrative dataset.

Ecuador (2000). The CAPB improved by 3.5 percent of GDP, but the policy record suggests a consolidation of 0.5 percent of GDP, implying a discrepancy of 3 percent of GDP (3.5-0.5). As discussed in David and Leigh (2018), the 0.5 percent of GDP in action-based consolidation reflects revenue measures of 1.3 percent of GDP that were partly offset by expenditure increases of 0.8 percent of GDP. The objective of the revenue measures was 
ensuring medium-term fiscal sustainability. Moreover, oil revenues increased by 3 percent of GDP in 2000 according to the 2003 Article IV staff report (EBS/03/21, Table 2 on page 28). Our conventional measure of the CAPB does not adjust for such swings in oil revenue, and this swing explains the gap compared to our narrative fiscal measure.

Jamaica (1992). The policy record suggests a consolidation of 2.1 percent of GDP, but our baseline measure of the CAPB falls by 2 percent of GDP, implying a discrepancy of 4.1 percent of GDP $(2.1+2)$. At the same time, the size of the CAPB fall is sensitive to the method of computing it. The WEO does not report CAPB data for Jamaica in 1992, and an alternative CAPB measure we construct based on the "rule of thumb" relating the adjusted balance as a share of GDP to the unadjusted balance and the output gap shows a fall of only 0.6 percent of GDP. ${ }^{17}$ So almost half of the discrepancy - 1.6 percent of GDP (2-0.6) - is due to differences in the CAPB versions. Of the remaining 2.5 percentage point discrepancy (4.11.6), most is explained by Bank of Jamaica. The 1993 Article IV consultation staff report (EBS/93/137) states (p. 3) that the deficit of the Central Government (including Bank of Jamaica losses) remained broadly constant in 1991/92 and 1992/93, while there was a modest improvement if such losses are excluded (see also Table 5 of the report). The report explains that policy measures - a widening of the tax base and more efficient tax enforcementcontributed to a rise in government revenue. In addition, the fiscal surplus of the rest of the public sector increased from 0.7 percent of GDP in 1991/92 to 3.3 percent of GDP in 1992/93, as public enterprises implemented fully the automatic cost pass-through mechanism and exercised additional capital expenditure restraint. Specific financial operations thus explain why the CAPB-based measure inaccurately identifies the size of deficit-driven fiscal consolidation.

Jamaica (1998). The CAPB rose by 3.7 percent of GDP, but this reflected fiscal tightening to restrain inflation and adjust to stabilizing international reserves. The 1998 Article IV consultation staff report (SM/98/165) presents (p. 17) the motivations for the authorities' actions: "The authorities explained that their program for FY 1998 had been framed in the context of a medium-term strategy that aims at achieving output growth of 4-5 percent by FY 2000 , reducing annual inflation to 3 percent by that year, and keeping international reserves at around the equivalent of 14 weeks of imports. In support of these objectives, the central government balance (excluding costs related to support of the financial system) would turn to a surplus of about 2.5 of GDP." The same report (p. 19) discusses the fiscal measuresmainly on the tax side - implemented by the authorities. Overall, much of the increase in the CAPB ratio in 1998 was the result of deliberate tightening to reduce inflation. We do not consider this as a fiscal consolidation motivated primarily by a desire to reduce the budget deficit.

${ }^{17} p b_{a d j}=p b-e^{*} g a p$, where $e$ is the ratio of primary expenditure to GDP. 
Jamaica (1999). The CAPB improved by 3.7 percent of GDP, but the policy record indicates a smaller action-based fiscal consolidation of 0.7 percent of GDP, implying a discrepancy of 3 percent of GDP. As discussed in David and Leigh (2018), the fiscal consolidation consisted of expenditure cuts of 0.7 percent of GDP on a net basis. The cuts aimed at reducing debt. The 2001 Article IV consultation staff report (EBS/01/73) suggests (p. 7) that a large part of the observed improvement in revenues amounting to about 2 percent of GDP was linked to one-off factors not accounted for in the CAPB measure, in particular bauxite and cellular license fees. In that context, we believe that the recorded changes in the cyclically adjusted primary balance do not accurately identify the size of the fiscal policy change.

Mexico (1995). The CAPB improved by 3 percent of GDP, but this reflects a policy response to prospective economic conditions in the context of a financial crisis. The fiscal consolidation occurred as part of an IMF-supported adjustment program. The 1995 Article IV consultation staff report (EBS/95/103) presents the motivation for the adjustment program on page 2: "In early January 1995, the Government of Mexico adopted an economic program to deal with the financial crisis that followed the sharp depreciation of the peso in late December 1994. This program, which was supported by a Fund stand-by arrangement, did not succeed in calming financial markets and in early March the authorities took additional measures. The new measures included greater fiscal adjustment and a tightening of monetary policy and were viewed as consistent with a sharp reduction in the external current account deficit." The first 1995 SBA review report (EBS/95/47) further discusses the motivations for the measures on page 6: "In the absence of a reinforcement of policies, Mexico's markedly less favorable economic outlook would have resulted in a significant worsening in its public finances with respect to the original program targets". An increase in the general VAT tax rate from 10 to 15 percent (except in border areas, where it remains at 10 per cent) effective as of May 1995, was one of the most main measures. The estimated impact of this increase in the VAT was of 1.2 percent of GDP (see p. 7 of the 1995 SBA first review staff report, EBS/95/47). Moreover, cuts in primary expenditures in the order of 1.4 percent of GDP were implemented (see Table 3 on page 29 of the 1997 Article IV staff report, SM/97/201). This included reductions in the wage bill ( 0.7 percent of GDP) and capital expenditures $(0.6$ percent of GDP). The discrepancy between the narrative and the CAPB measures is in this case explained by the direct response to the balance of payments crisis and prospective economic conditions.

Paraguay (1989). The CAPB improved by 5.2 percent of GDP, but the policy record shows an action-based fiscal consolidation amounting to 2.6 percent of GDP, implying a discrepancy of 2.6 percent of GDP (5.2-2.6). The Situación Financiera for the central government downloaded from the Ministry of Finance's website

(http://www.hacienda.gov.py/situfin/) indicates that tax revenue increased by about 2 percent of GDP in 1989, reflecting the budgetary impact of tax measures presented in David and Leigh (2018). The motivation for these measures was the need to reduce the fiscal deficit. The 1991 Article IV staff report (SM/91/160) states on page 2 that: "To address the country's 
economic imbalances, the Government that took office in 1989 tightened fiscal and credit policy, unified the exchange rate under a managed float, and liberalized the financial and trade systems. In the fiscal area, the authorities increased government revenue, raised public tariffs, improved the operational efficiency of public enterprises, and reduced investment spending. In addition, they took steps to improve tax administration and combat evasion."

On top of these policy-driven tax increases, however, non-tax revenues increased substantially, reflecting additional royalty revenue from energy sales by the Itaipú binational hydroelectricity plant, which increased by about 1.4 percent of GDP in 1989, mostly explained by favorable weather conditions. Hence, a large share of the discrepancy can be explained by non-policy factors that were not adjusted for in our measure of the CAPB, which only considers adjustments for the economic cycle. In that context, we believe that the recorded changes in the cyclically adjusted primary balance do not accurately identify the size of the fiscal policy change.

Paraguay (1990). The CAPB improved by 3.7 percent of GDP, but this reflected policy actions to reduce inflation and stabilize reserves. The 1991 SBA request report (EBS/91/5) presents (p. 5) the objectives of the authorities' program for 1990: "In early 1990, the authorities discussed with the staff an economic program ... aimed at a reduction in the 12month rate of inflation to below 20 percent by the end of 1990, a modest buildup of international reserves ... The achievement of these objectives was premised on the continuation of the prudent fiscal stance, a tightening of credit policy, and adjustments in domestic interest rates." The report confirms (p. 6) that the strong fiscal outturn reflected: "cutbacks in current and capital spending by the public sector." A policy response to prospective economic conditions thus explains the gap between the CAPB-based indicator and our narrative measure.

Paraguay (1998). The CAPB improved by 2.9 percent of GDP, but this reflected a policy response to economic activity. A new administration took office in August 1998 and implemented a number of measures to increase revenue for the rest of the year, including increases in excise duties and tax administration improvements. The motivation for these policy measures are discussed in the 1999 Recent Economic Developments report (IMF country report 99/10) as follows (p. 9): “A cooling Brazilian economy and stricter border controls reduced reexport trade and receipts from trade taxes. In addition, declining economic activity in Paraguay and slackening collection efforts diminished revenues from the corporate income tax. ... To help restore the fiscal balance, the administration that assumed office in August 1998 has the list of exemptions from the VAT and import tariffs ... and increased excise taxes on fuel, alcohol, and cigarettes. In addition, a campaign of on-site controls in business has led to an increase in the collection of VAT and corporate income taxes during the last months of 1998." 
The 1998 Article IV staff report (SM/98/277) provides an indirect estimate of the impact of the measures in the order of 2 percent of GDP (p. 4): "In 1998, the continued increase in current spending, especially on wages, at a time when the weakness in economic activity was eroding the tax base, resulted in a deficit that by mid-year was approaching 3 percent of GDP on a twelve-month rolling basis. Upon assuming office in mid-August, the incoming administration took measures to contain the deficit, including a decree (Decree No. 6) to reduce current expenditure, the reduction of some tax exemptions, and a significant tightening of tax administration, including for imports and border trading. With these measures, the deficit for 1998 as a whole is now estimated to be 1\% percent of GDP, just above that of 1997." In addition, windfall gains from Itaipú also helped boost the fiscal balance. Page 10 of the 1999 Recent Economic Developments report (IMF country report 99/10) states that the royalties from Itaipú increased to 2.8 percent of GDP in 1998 because of the weather, 0.9 percent of GDP higher than in 1996. The gap between the CAPB and our narrative measure thus reflects a policy response to economic conditions as well as nonpolicy factors not accounted for in the CAPB adjustment measure.

Overall, our examination of these 16 largest discrepancies between the CAPB-based approach and the narrative approach suggests that our narrative approach more accurately identifies the size of deficit-driven fiscal consolidation. The discrepancies are generally driven by specific economic or budgetary developments that cause the conventional CAPBbased measure to inaccurately identify the size of deficit-driven fiscal consolidation. These developments include, in a number of cases, responses to current or prospective economic conditions, including the onset of economic crisis. 
Figure A1. Overlap Check: Empirical Distributions of the Treatment Propensity Score
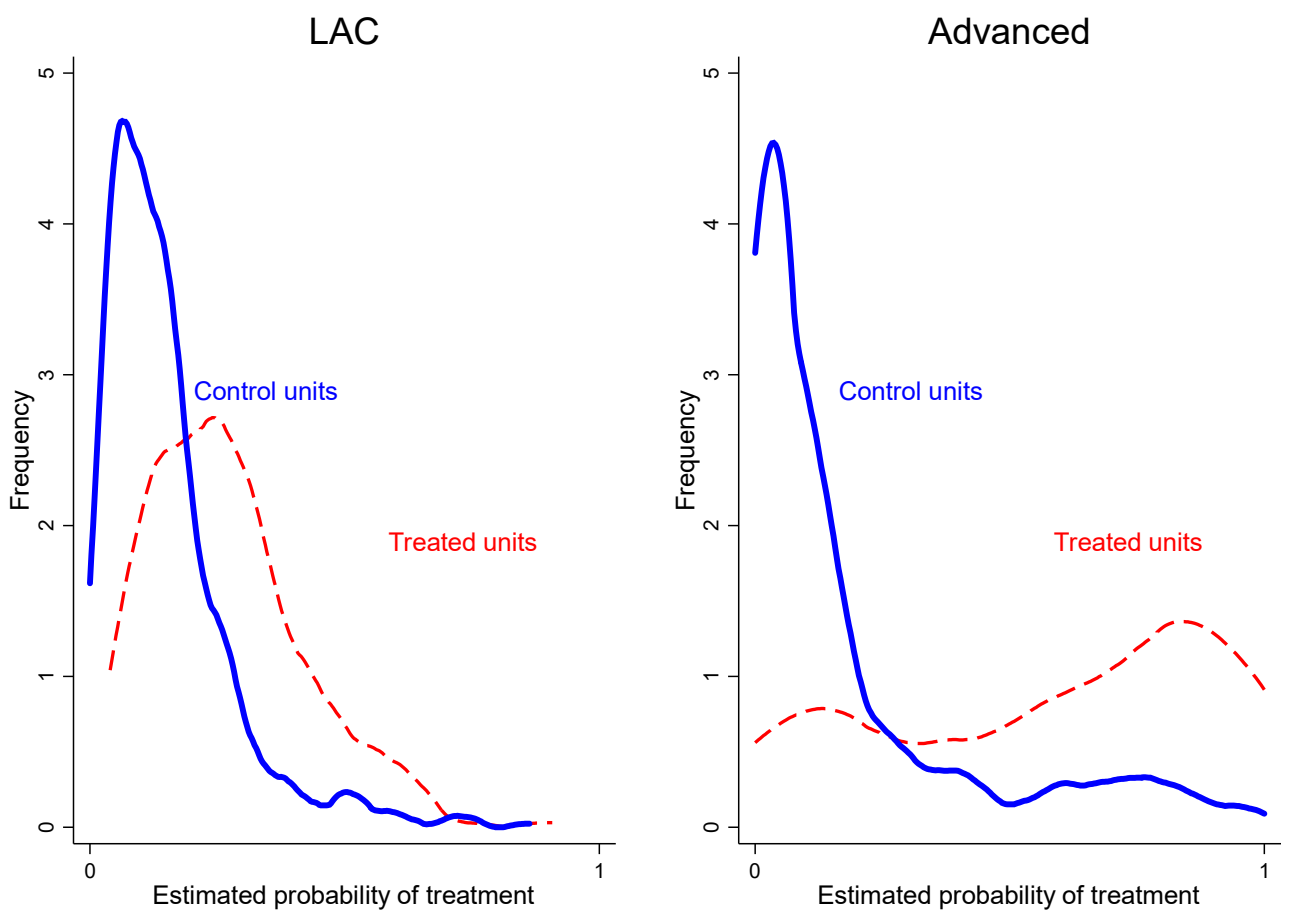